\title{
Blood glycemia-modulating effects of melanian snail protein hydrolysates in mice with type II diabetes
}

\author{
JAE-SUK CHOI $^{1 *}$, JOO-WAN KIM ${ }^{2 *}$, JEONG BEEN PARK ${ }^{1}$, SANG EUN PYO ${ }^{1}$, \\ YONG-KI HONG ${ }^{3}$, SAE KWANG KU ${ }^{4}$ and MI-RYUNG KIM ${ }^{1}$
}

\begin{abstract}
${ }^{1}$ Major in Food Biotechnology, Division of Bioindustry, College of Medical and Life Sciences, Silla University, Sasang-gu, Busan 46958; ${ }^{2}$ Aribio Inc., Byeoksan Digital Valley, Yeongdeungpo-gu, Seoul 07286; ${ }^{3}$ Department of Biotechnology, College of Fisheries Science, Pukyong National University, Nam-Gu, Busan 48513; ${ }^{4}$ Department of Anatomy and Histology, College of Oriental Medicine, Daegu Haany University, Gyeongsan-si, Gyeongsangbuk-do 38610, Republic of Korea
\end{abstract}

Received September 19, 2016; Accepted March 29, 2017

DOI: $10.3892 / \mathrm{ijmm} .2017 .2967$

\begin{abstract}
Freshwater animal proteins have long been used as nutrient supplements. In this study, melanian snail (Semisulcospira libertina) protein hydrolysates (MPh) were found to exert anti-diabetic and protective effects against liver and kidney damage in mice with type II diabetes adapted to a $45 \%$ kcal high-fat diet (HFD). The hypoglycemic, hepatoprotective and nephroprotective effects of MPh were analyzed after 12 weeks of the continuous oral administration of MPh at 125 , 250 and $500 \mathrm{mg} / \mathrm{kg}$. Diabetic control mice exhibited an increase in body weight, and blood glucose and insulin levels, with a decrease in serum high-density lipoprotein (HDL) levels. In addition, an increase in the regions of steatohepatitis, hepatocyte hypertrophy, and lipid droplet deposit-related renal tubular vacuolation degenerative lesions were detected, with noticeable expansion and hyperplasia of the pancreatic islets, and an increase in glucagon- and insulin-producing cells, insulin/glucagon cell ratios in the endocrine pancreas and hepatic lipid peroxidation, as well as decreased zymogen contents. Furthermore, a deterioration of the endogenous antioxidant defense system was observed, with reduced glucose utilization related hepatic glucokinase (GK) activity and an increase in hepatic gluconeogenesis-related phosphoenolpyruvate carboxykinase (PEPCK) and glucose-6-phosphatase (G6pase) activity. However, all of
\end{abstract}

Correspondence to: Professor Mi-Ryung Kim, Major in Food Biotechnology, Division of Bioindustry, College of Medical and Life Sciences, Silla University, 140 Baegyang-daero 700beon-gil, Sasang-gu, Busan 46958, Republic of Korea

E-mail: haha7kmr@silla.ac.kr

Professor Sae Kwang Ku, Department of Anatomy and Histology, College of Oriental Medicine, Daegu Haany University, 1 Hanuidae-ro, Gyeongsan-si, Gyeongsangbuk-do 38610, Republic of Korea

E-mail: gucci200@hanmail.net

*Contributed equally

Key words: melanian snail, Semisulcospira libertina, protein hydrolysates, blood glycemia-modulating effects, anti-diabetic effects these diabetic complications were significantly inhibited by oral treatment with MPh in a dose-dependent manner. In addition, the marked dose-dependent inhibition of hepatic lipid peroxidation, the depletion of the liver endogenous antioxidant defense system, and changes in hepatic glucose-regulating enzyme activities were also observed. The results of this study suggest that $\mathrm{MPh}$ exerts potent anti-diabetic effects, along with the amelioration of related complications in mice with type II diabetes. The overall effects of MPh at a dose of $125 \mathrm{mg} / \mathrm{kg}$ on HFD-induced diabetes and related complications were similar or more potent than those of metformin $(250 \mathrm{mg} / \mathrm{kg})$.

\section{Introduction}

Recently, there has been a worldwide increase in the incidence of type II diabetes associated with obesity, the development of which seems to be due to a combination of high-caloric diets and physical inactivity $(1,2)$. The predicted estimates suggest that the worldwide population with this syndrome may double to over 300 million by the year 2025 (3). Triglyceride (TG) accumulation in tissues, particularly in fatty tissues, is associated with the excessive intake of fatty acids. The excess of fatty acids in non-adipose tissues has been linked to the higher circulation of fatty acids and insulin (2). Insulin resistance has been shown to be associated with higher levels of fatty acid binding, and a higher availability of transport proteins in adipose and non-adipose tissues, which facilitate the uptake of fatty acid by these tissues. The higher levels of free fatty acid (FFA) deposition in muscle trigger a negative feedback in glucose utilization and the insulin-mediated muscle insulin signaling pathway (4). Prolonged exposure to FFAs in the pancreas may cause impaired insulin release through lipotoxicity (5). High FFA concentrations in the liver resist the action of insulin by enhancing glucose output (6). The accumulation of TGs in the liver causes non-alcoholic fatty liver disease (NAFLD). The liver is the main organ for glucose metabolism and NAFLD damages the liver via hepatocellular necrosis, steatosis, fibrosis and steatohepatitis (7). The imbalanced lipolysis and hepatic lipogenesis causes NAFLD and insulin resistance (8).

It has been reported that oxidative stress inhibition and the control of post-prandial hyperglycemia play an important 
role in the treatment of diabetes (9). Hence, safe and effective $\alpha$-glucosidase inhibitors, antioxidants and functional food materials from natural sources have been the focus of research $(10,11)$. For example, metformin, an orally administrated anti-diabetic drug from the biguanide class has been used in the treatment of type II diabetes (12). The most severe potential side-effect of metformin is lactic acidosis, although the occurrence of this phenomenon is very rare and it has been mostly related to comorbid conditions, i.e., impaired kidney or liver function (13).

Protein hydrolysates have evolved to the point where they are promising nutrient supplements for use in clinical and elemental nutrition, in the treatment of weight loss, as well as malnutrition associated with various clinical conditions (14). Fish hydrolysates, which have been suggested to be advantageous protein nutritional supplements for different medical conditions $(15,16)$, also have antioxidant, antimicrobial and antiproliferative effects (17). In particular, some protein hydrolysates have been shown to exert hypolipidemic and anti-obesity effects in high-fat diet (HFD)-fed obese animal models (18-21). The melanian snail, Semisulcospira libertina, is one of the most commonly encountered freshwater snails in Far East Asia, and has been used as an ingredient of tonic functional foods in Korea (22-24).

The present study was performed to examine the pharmacological anti-diabetic activity, and ameliorating effects with respect to related complications, of melanian snail (Semisulcospira libertina) protein hydrolysates (MPh) in mice with type II diabetes.

\section{Materials and methods}

Animals. In total, 50 female specific pathogen-free (SPF) ICR mice (6 weeks old upon receipt; OrientBio, Seungnam, Korea) were used in the experiments after a 7-day period of acclimatization to the laboratory environment. The animals were allocated 4-5 per polycarbonate cage in a temperature $\left(20-25^{\circ} \mathrm{C}\right)$ - and humidity (40-45\%)-controlled room under a 12:12-h light:dark cycle with free access to commercial rodent chow (Samyang, Seoul, Korea) and water. The animals were allocated to 6 groups following a 1-week adaptation period ( $\mathrm{n}=8 \mathrm{mice} / \mathrm{group}$; total of $40 \mathrm{HFD}$-fed mice and 8 normal diet-fed mice as the intact group) based on body weight (intact control: mean, $29.60 \pm 1.59 \mathrm{~g}$; HFD group: mean, $32.33 \pm 1.63 \mathrm{~g}$ ). The formulas of the normal diets and HFDs used in this study are shown in Table I. All laboratory animals were treated according to the national regulations for the usage and welfare of laboratory animals, and the protocol was approved by the Institutional Animal Care and Use Committee of Daegu Haany University (Gyeongsan, Gyeongbuk, Korea) prior to the experiments (approval no. DHU2015-017).

Preparation and administration of test agents. Green powders of MPh were prepared by the following method: briefly, melanian snail meat samples were warmed at $50^{\circ} \mathrm{C}$ for $10 \mathrm{~min}$, mixed with 5 volumes of distilled water, and then reacted with Protamax $(\mathrm{E} / \mathrm{S}=3.6 \mathrm{AU} / \mathrm{g})$ at $50^{\circ} \mathrm{C}$ for $10 \mathrm{~min}$ with shaking at $300 \mathrm{rpm}$. The enzyme activities were then inhibited by heating in a water bath at $95^{\circ} \mathrm{C}$ for $15 \mathrm{~min}$. Finally, the samples were centrifuged at 1,500 x g (Sorvall Legend Micro 17; Thermo Fisher Scientific Inc., Waltham, MA, USA) for $10 \mathrm{~min}$, and the
Table I. Formulas of normal and high-fat diets used in this study.

\begin{tabular}{lcc}
\hline Composition & $\begin{array}{c}\text { Normal pellet diet } \\
(\mathrm{g} / \mathrm{kg} \text { diet })\end{array}$ & $\begin{array}{c}\text { High-fat diet } \\
(\mathrm{g} / \mathrm{kg} \text { diet })^{\mathrm{a}}\end{array}$ \\
\hline Ingredient & & \\
Casein & 200 & 200 \\
L-cysteine & 3 & 3 \\
Corn starch & 150 & 72.8 \\
Sucrose & 500 & 172.8 \\
Cellulose & 50 & 50 \\
Soybean oil & 50 & 25 \\
Lard & 0 & 177.5 \\
Mineral mixture & 35 & 10 \\
Vitamin mixture & 10 & 10 \\
Choline bitartrate & 2 & 2 \\
Energy $(\mathrm{kcal} / \mathrm{g})$ & 0.21 & 4.73 \\
Protein $(\% \mathrm{kcal} / \mathrm{kg})$ & 13.3 & 20 \\
Carbohydrate $(\% \mathrm{kcal} / \mathrm{kg})$ & 47.4 & 35 \\
Fat $(\% \mathrm{kcal} / \mathrm{kg})$ & 8.0 & 45 \\
Fiber $(\% \mathrm{kcal} / \mathrm{kg})$ & 8.0 & 8.0 \\
\hline
\end{tabular}

aPellet diets 45\% kcal/fat (D12451; Research Diet, New Brunswick, NJ, USA) were used as high-fat diet (HFD) and normal rodents pellet diet (Superfeed Co., Seoul, Korea) were used as normal fat pellet diets.

supernatants were completely lyophilized. The MPh samples thus obtained were stored at $-20^{\circ} \mathrm{C}$ and protected against light and humidity until use. Some MPh samples were deposited in the herbarium of the Medical Research Center for Globalization of Herbal Formulation, Daegu Haany University (encoded as MPh2015Ku01). Metformin hydrochloride (Wako, Osaka, Japan) was used as a reference.

$\mathrm{MPh}$ dissolved in distilled water was administered orally, at doses of 125,250 and $500 \mathrm{mg} / \mathrm{kg}$, once a day for 84 days after 7 days of HFD adaptation. Metformin dissolved in distilled water was also administered orally at $250 \mathrm{mg} / \mathrm{kg}$. The intact vehicle and diabetic control mice received an oral administration of equal volumes of distilled water.

Changes in body and organ weight. Body weight was measured just before commencement of the HFD regime. One day before the initiation of MPh administration, on the first administration day (day 0 ), and then weekly until termination on day 84 using an automatic electronic balance (Precisa Instruments, Dietikon, Switzerland). At initiation and termination of administration, all experimental animals were fasted overnight with access only to water (approximately $12 \mathrm{~h}$ ) to reduce differences due to feeding. In addition, body weight gain was calculated during the adaptation period (from day -8 to 0 of test agent administration) and administration period (from day 0-84 of test agent administration) as follows:

Equation [1], body weight gain (g): during the 7-day adaptation period = body weight at initiation of administration - body weight at initiation of HFD supply (from day -8 to 0 of test 
agent administration); and during the 84-day administration period $=$ body weight at termination - body weight at initiation of administration (from day 0-84 of test agent administration).

At sacrifice, the weights of the liver, pancreas and left kidney were determined individually and to minimize the effect of inter-individual difference in body weight, the relative weights (\% of body weight) were also calculated by means of body weight at sacrifice.

Mean daily food consumption measurements. Diets of $150 \mathrm{~g}$ in each individual cage were supplied, with the remaining amount of food measured after $24 \mathrm{~h}$ via an automatic electronic balance (Precisa Instruments). That amount was then divided by the number of animals reared in the cage. These measurements were conducted once a week for 84 days during the administration period, as previously described $(25,26)$.

Measurement of serum biochemistry levels. For the measurement of blood glucose levels, blood samples were collected from the caudal vena cava into NaF glucose vacuum tubes (BectonDickinson, Franklin Lakes, NJ, USA) and plasma was separated at sacrifice. Blood glucose levels were measured using an automated blood glucose analyzer (200 FR; Toshiba, Tokyo, Japan). For other serum biochemistry measurements, blood samples were collected from the caudal vena cava into clotting activated serum tubes. The samples were centrifuged at $16,200 \mathrm{x} g$ for $10 \mathrm{~min}$ at ambient temperature. The alanine aminotransferase (ALT), serum aspartate aminotransferase (AST), blood urine nitrogen (BUN), TG, total cholesterol (TC), creatinine, low-density lipoprotein (LDL), high-density lipoprotein (HDL) cholesterol and cholesterol levels were measured using an automated blood analyzer (Hemagen Analyst Hemagen Diagnostic, Columbia, MD, USA), while serum LDL and HDL levels were detected using different blood analyzer (AU400; Olympus, Tokyo, Japan). Serum insulin and blood HbA1c levels were measured using a HbA1c measuring system (Infopia, Anyang, Korea) and an enzyme-linked immunosorbent assay (ELISA) kit (Alpco Diagnostics, Windham, NH, USA), as previously described $(27,28)$.

Lipid peroxidation and liver antioxidant defense system. Before measuring the lipid peroxidation and antioxidant activities, organ weights were measured. Glutathione (GSH) and malondialdehyde (MDA) contents, and the enzyme activities of superoxide dismutase (SOD) and catalase (CAT) in mouse hepatic tissues, were measured. Liver tissues were weighed and homogenized in ice-cold $0.01 \mathrm{M}$ Tris- $\mathrm{HCl}(\mathrm{pH} 7.4)$, and centrifuged at $12,000 \mathrm{x}$ g for $15 \mathrm{~min}$, as previously described by Kavutcu et al (29). Lipid peroxidation in the liver was determined by estimating MDA contents using the thiobarbituric acid test at absorbance $525 \mathrm{~nm}$ as $\mathrm{nM}$ of MDA $\mathrm{mg}^{-1}$ tissue (30). Total protein contents were measured using a previously described method (31) and bovine serum albumin (BSA) (Invitrogen, Carlsbad, CA, USA) was used as an internal standard. Prepared homogenates were mixed with $0.1 \mathrm{ml}$ of 25\% trichloroacetic acid (Merck, San Francisco, CA, USA), and centrifuged at $1,700 \times \mathrm{g}$ for $40 \mathrm{~min}$ at $4^{\circ} \mathrm{C}$. GSH contents were determined by measuring the absorbance at $412 \mathrm{~nm}$ using 2-nitrobenzoic acid (Sigma-Aldrich, St. Louis, MO, USA) as $\mu \mathrm{M} / \mathrm{mg}$ tissue (32). $\mathrm{H}_{2} \mathrm{O}_{2}$ decomposition in the presence of
CAT was measured at $240 \mathrm{~nm}$, as previously described (33). CAT activity was defined as the amount of enzyme required to decompose $1 \mathrm{nM} \mathrm{H} \mathrm{O}_{2} / \mathrm{min}$ at $25^{\circ} \mathrm{C}, \mathrm{pH} 7.8$ and the results are expressed as $\mathrm{U} / \mathrm{mg}$ tissue. SOD activity was measured according to the method described by Sun et al (34). The estimation of SOD activity was based on superoxide radical generation by xanthine and xanthine oxidase, which react with nitrotetrazolium blue to form formazan dye. SOD activity was measured at absorbance $560 \mathrm{~nm}$ as the degree of inhibition of this reaction, and was expressed as U/mg tissue. One unit of SOD enzymatic activity was equivalent to the amount of enzyme that reduced the initial absorbance of nitroblue tetrazolium by $50 \%$ in $1 \mathrm{~min}$.

Measurement of hepatic glucose-regulating enzyme activities. The hepatic enzyme source was prepared based on the method described by Hulcher and Oleson (35). Briefly, $0.3 \mathrm{~g}$ of hepatic tissue was homogenized in buffer solution (0.1 M triethanolamine, 0.2 MEDTA and 0.002 M dithiothreitol), and centrifuged at $1,000 \mathrm{x}$ g for $15 \mathrm{~min}$ at $4^{\circ} \mathrm{C}$. The supernatant was centrifuged again at $10,000 \times \mathrm{g}$ for $15 \mathrm{~min}$ at $4^{\circ} \mathrm{C}$. Glucokinase (GK) activity was measured according to the method described by Davidson and Arion (36) with slight modifications. Briefly, $0.98 \mathrm{ml}$ of the reaction mixture $\left[100 \mathrm{mM} \mathrm{KCl}, 50 \mathrm{mM} \mathrm{NAD}^{+}\right.$, $50 \mathrm{mM}$ HEPES-NaGT, pH 7.4, $10 \mathrm{mM}$ glucose, $7.5 \mathrm{mM} \mathrm{MgCl}_{2}$, $2.5 \mathrm{mM}$ dithioerythritol, $10 \mu \mathrm{l}$ of hepatic tissue homogenate, 4 units of glucose-6-phosphate dehydrogenase (G6PDH) and $10 \mathrm{mg} / \mathrm{ml}$ albumin], was pre-incubated at $37^{\circ} \mathrm{C}$ for $10 \mathrm{~min}$. The reaction was initiated by the addition of $10 \mu \mathrm{l}$ of $5 \mathrm{mM}$ ATP, and the mixture was incubated at $37^{\circ} \mathrm{C}$ for $10 \mathrm{~min}$. The variation in absorbance at $340 \mathrm{~nm}$ was recorded. Glucose-6phosphatase (G6pase) activity was measured by following the method described by Alegre et al (37). The reaction mixture contained $765 \mu \mathrm{l}$ of $131.58 \mathrm{mM}$ HEPES-NaGT (pH 6.5), $100 \mu \mathrm{l}$ of $265 \mathrm{mM}$ glucose-6-phosphate, $100 \mu \mathrm{l}$ of $18 \mathrm{mM}$ EDTA (pH 6.5), $10 \mu 1$ of $0.2 \mathrm{M} \mathrm{NADP}+, 0.6 \mathrm{IU} / \mathrm{ml}$ glucose dehydrogenase and $0.6 \mathrm{IU} / \mathrm{ml}$ mutarotase. A total of $5 \mu \mathrm{l}$ of the pre-incubated hepatic tissue homogenate at $37^{\circ} \mathrm{C}$ was added to the mixture and incubated again at $37^{\circ} \mathrm{C}$ for $4 \mathrm{~min}$. The change in absorbance at $340 \mathrm{~nm}$ was recorded. The phosphoenolpyruvate carboxykinase (PEPCK) activity was assessed using the Bentle and Lardy (38) method. The reaction mixture contained $500 \mathrm{mM} \mathrm{NaHCO}$, $200 \mathrm{mM}$ PEP, $100 \mathrm{mM}$ IDP, $72.92 \mathrm{mM}$ sodium HEPES (pH 7.0), $25 \mathrm{mM} \mathrm{NADH,} 10 \mathrm{mM} \mathrm{MnCl}_{2}$, $10 \mathrm{mM}$ dithiothreitol, $10 \mu \mathrm{l}$ of hepatic tissue homogenate and 7.2 units of malic dehydrogenase. The hepatic enzyme activity was measured based on the decrease in absorbance of the mixture at $340 \mathrm{~nm}$ at $25^{\circ} \mathrm{C}$. All reagents and chemicals used in this hepatic enzyme activity measurement were obtained from Sigma-Aldrich.

Histopathology. After measuring organ weights, the splenic lobes of the pancreas and the left lateral lobes of the left kidney and liver were fixed in $10 \%$ neutral-buffered formalin, embedded in paraffin and cut into serial sections of 3-4 $\mu \mathrm{m}$ thickness. Representative sections were stained with hematoxylin and eosin (H\&E; Sigma-Aldrich) for light microscopy (microscope: Eclipse 80i; Nikon Corp., Tokyo, Japan). The histological profiles of individual organs were then examined. Alternatively, the liver portions dehydrated in $30 \%$ sucrose solution were cut into frozen sections on a cryostat for staining 
with Oil Red O (Alfa Aesar, Heysham, UK), as previously described $(39,40)$. To observe more detail histopathological changes, the steatohepatitic regions and mean hepatocyte diameter (H\&E staining) were calculated by automated image analysis (iSolution FL ver. 9.1; IMT i-solution Inc., Vancouver, QC, Canada) on the restricted view fields according to previously described methods $(25,26,39,40)$. Steatohepatitic regions, i.e., regions with fatty deposits in the hepatic parenchyma, were calculated as a percentage of lipid deposition regions on cryostat sections with Oil Red staining using a microscope with an automated image analysis program (\% $\mathrm{mm}^{-2}$ of hepatic parenchyma). The mean diameter $(\mu \mathrm{m})$ of hepatocytes was also calculated by an automated image analysis program using H\&E staining; at least 10 hepatocytes were examined per view field of the liver. In addition, means of vacuolated renal tubules with lipid droplet deposition were calculated using an automated image analysis program (number $100^{-1}$ tubules; one field/sample); the mean area occupied by zymogen granules $\left(\% \mathrm{~mm}^{-2}\right.$ of pancreatic parenchyma), diameters $(\mu \mathrm{m})$ of pancreatic islets, as well as the numbers (islets $/ 10 \mathrm{~mm}^{2}$ of pancreatic parenchyma) were also measured using an automated image analysis program according to previously established methods $(25,26,40)$. The histopathologist was blinded to group allocation at the time of the analysis.

Immunohistochemistry. Serial sections of other pancreatic tissues (remaining tissue after $\mathrm{H} \& \mathrm{E}$ staining) were immunostained by the avidin-biotin-peroxidase (ABC) method (40) using rabbit polyclonal anti-glucagon (dilution 1:2,000; Cat. no. ab133195, Abcam, Cambridge, MA, USA) or guinea pig polyclonal anti-insulin (dilution 1:2000; Cat. no. ab7842, Abcam) (both from DiaSorin, Stillwater MN, USA) antiserum. Briefly, endogenous peroxidase activity was blocked by incubating in $0.3 \% \mathrm{H}_{2} \mathrm{O}_{2}$ and methanol for $30 \mathrm{~min}$, and non-specific binding of immunoglobulin was blocked with normal horse serum blocking solution (dilution 1:100; Vector Laboratories, Burlingame CA, USA) for $1 \mathrm{~h}$ in a humid chamber. Treatment with primary antiserum was performed overnight at $4^{\circ} \mathrm{C}$ in a humid chamber, followed by incubation with biotinylated universal secondary antibody (dilution 1:50; Cat. no. PK-6200; Vector Laboratories) and $\mathrm{ABC}$ reagents (dilution 1:50, Vectastain Elite ABC kit; Vector Laboratories) for $1 \mathrm{~h}$ at room temperature in a humid chamber. Finally, the sections were reacted with the peroxidase substrate kit (Vector Laboratories) for $3 \mathrm{~min}$ at room temperature. All sections were rinsed 3 times in $0.01 \mathrm{M}$ phosphate-buffered saline (PBS) between steps. Immunoreactive cell densities over $20 \%$ as compared with other naïve cells were regarded as positive, and the positive cells were assessed based on mean areas of pancreatic islets $\left(\mathrm{mm}^{2}\right)$ using the automated image analysis, as previously described $(41,40)$. The ratios of insulin-positive/glucagon-positive cells were calculated as shown below in equation [2]. The histopathologist was blinded to the group allocation at the time of the analysis.

Equation [2]:

$$
\text { Insulin positive/glucagon positive cells (ratio) }=\frac{\mathrm{A}}{\mathrm{B}}
$$

where, A represents the mean number of insulin immunoreactive cells, and B represents the mean number of glucagon immunoreactive cells.
Statistical analyses. All numerical values are expressed as the means \pm standard deviation (SD) of 8 mice. Multiple comparison tests of the different dose groups were conducted. Homogeneity of variance was examined using Levene's test (42). In case of no significant deviations detected from homogeneity of variance by Levene's test, the data were analyzed by one-way ANOVA followed by the least-significant differences multicomparison (LSD) test to determine the significantly different group pairs. In case of significant deviations from homogeneity of variance on Levene's test, the non-parametric KruskalWallis $\mathrm{H}$ test was conducted. When a significant difference was observed on the Kruskal-Wallis H test, the Mann-Whitney $\mathrm{U}$ test was performed to determine the significantly different specific group pairs. Statistical analyses were performed using SPSS software (ver. 14.0; SPSS Inc., Chicago, IL, USA), as previously described (43). The efficacy of the test agents was calculated by comparing the percentage changes with HFD control, and the assess disease induction was assessed by calculating the percentage changes between intact and HFD controls according to equations [3] and [4], as previously described (40).

Equation [3]:

$\%$ changes compared with intact control $=\frac{\begin{array}{l}\text { Data of HFD control- } \\ \text { Data of intact control }\end{array}}{\text { Data of intact control }} \times 100$

Equation [4]:

$\%$ changes compared with HFD control $=\frac{\begin{array}{c}\text { Data of test agent treated mice- } \\ \text { Data of HFD control }\end{array}}{\text { Data of HFD control }} \times 100$

\section{Results}

Changes in body weight and food consumption. We selected only adapted mice exhibiting a regular body weight increase as compared to the intact (normal diet) controls during 1 week of HFD supply (intact control: mean, $29.60 \pm 1.59 \mathrm{~g}$; range, 27.30-32.20 g; HFD group: mean, $32.33 \pm 1.63 \mathrm{~g}$; range, 29.70-35.80 g). HFD control mice exhibited significant $(\mathrm{p}<0.01)$ increases in body weight compared with the intact controls from 1 week after commencement of being fed the HFD; accordingly, body weight gains during the 7-day HFD adaptation period and 84-day administration period were also significantly increased compared with the intact controls (both $\mathrm{p}<0.01)$. However, significant $(\mathrm{p}<0.01$ or $\mathrm{p}<0.05)$ decreases in body weight were detected in mice treated with metformin at $250 \mathrm{mg} / \mathrm{kg}$, or $\mathrm{MPh}$ at 125,250 and $500 \mathrm{mg} / \mathrm{kg}$; accordingly, body weight gains during the 84 days of administration were also significantly decreased in these groups compared with the HFD controls (all $\mathrm{p}<0.01$ ) (Table II).

Although a significant $(\mathrm{p}<0.01)$ decrease in mean daily food consumption was detected in all HFD-fed mice compared with the intact controls, no significant changes were observed in mean daily food consumption in any of the test agent groups (Table II).

\section{Anti-diabetic effects}

Effects on pancreatic weight changes. A significant $(\mathrm{p}<0.01)$ decrease in the relative pancreas weight was identified in the HFD control mice compared with the intact controls. However, 
Table II. Changes on body weight gain and mean daily food consumption in mice with type II diabetes.

\begin{tabular}{|c|c|c|c|c|c|c|c|}
\hline \multirow[b]{2}{*}{ Group } & \multicolumn{4}{|c|}{ Body weight $(\mathrm{g})$ at days after initial test substance treatment } & \multicolumn{2}{|c|}{ Body weight gain during } & \multirow[b]{2}{*}{$\begin{array}{l}\text { Mean daily food } \\
\text { consumption }(\mathrm{g})\end{array}$} \\
\hline & $\begin{array}{c}8 \text { days } \\
\text { before }[\mathrm{A}]\end{array}$ & $\begin{array}{c}1 \text { day } \\
\text { before }[\mathrm{B}]\end{array}$ & $\begin{array}{c}0 \text { day }^{\mathrm{a}} \\
\text { before }[\mathrm{C}]\end{array}$ & $\begin{array}{l}84 \text { days }^{\mathrm{a}} \\
\text { [D] }\end{array}$ & $\begin{array}{c}\text { Adaptation period } \\
{[\mathrm{B}-\mathrm{A}]}\end{array}$ & $\begin{array}{l}\text { Administration } \\
\text { period [D-C] }\end{array}$ & \\
\hline \multicolumn{8}{|l|}{ Controls } \\
\hline Intact & $29.03 \pm 1.51$ & $29.60 \pm 1.59$ & $27.13 \pm 1.70$ & $32.65 \pm 2.52$ & $0.58 \pm 0.36$ & $5.53 \pm 1.46$ & $5.30 \pm 0.63$ \\
\hline HFD & $28.94 \pm 1.81$ & $32.38 \pm 2.00^{\mathrm{b}}$ & $30.10 \pm 1.89^{\mathrm{b}}$ & $49.95 \pm 6.45^{\mathrm{c}}$ & $3.44 \pm 1.22^{\mathrm{c}}$ & $19.85 \pm 7.10^{\mathrm{c}}$ & $4.05 \pm 0.41^{\mathrm{c}}$ \\
\hline \multicolumn{8}{|l|}{ Reference } \\
\hline Metformin & $28.98 \pm 1.48$ & $32.34 \pm 1.58^{\mathrm{b}}$ & $30.13 \pm 1.57^{b}$ & $38.41 \pm 1.72^{\mathrm{c}, \mathrm{e}}$ & $3.36 \pm 1.12^{\mathrm{c}}$ & $8.29 \pm 1.93^{\mathrm{c}, \mathrm{e}}$ & $4.09 \pm 0.61^{\mathrm{c}}$ \\
\hline \multicolumn{8}{|l|}{ MPh-treated } \\
\hline $500 \mathrm{mg} / \mathrm{kg}$ & $28.98 \pm 1.55$ & $32.31 \pm 1.60^{\mathrm{b}}$ & $30.20 \pm 1.18^{\mathrm{b}}$ & $34.93 \pm 0.92^{\mathrm{d}, \mathrm{e}}$ & $3.34 \pm 0.63^{\mathrm{c}}$ & $4.73 \pm 1.95^{\mathrm{e}}$ & $4.02 \pm 0.69^{\mathrm{c}}$ \\
\hline $250 \mathrm{mg} / \mathrm{kg}$ & $28.98 \pm 1.60$ & $32.28 \pm 1.65^{\mathrm{b}}$ & $30.06 \pm 1.61^{\mathrm{b}}$ & $35.26 \pm 2.12^{\mathrm{d}, \mathrm{e}}$ & $3.30 \pm 0.24^{\mathrm{c}}$ & $5.20 \pm 2.13^{\mathrm{e}}$ & $4.09 \pm 0.40^{\mathrm{c}}$ \\
\hline $125 \mathrm{mg} / \mathrm{kg}$ & $29.04 \pm 1.70$ & $32.31 \pm 1.81^{\mathrm{b}}$ & $29.98 \pm 1.74^{b}$ & $37.68 \pm 2.31^{\mathrm{c}, \mathrm{e}}$ & $3.28 \pm 0.36^{\mathrm{c}}$ & $7.70 \pm 2.15^{\mathrm{e}}$ & $4.09 \pm 0.49^{c}$ \\
\hline
\end{tabular}

Table III. Changes on absolute and relative organ weights in mice with type II diabetes.

\begin{tabular}{|c|c|c|c|c|c|c|}
\hline \multirow[b]{2}{*}{ Group } & \multicolumn{3}{|c|}{ Absolute organ weight (g) } & \multicolumn{3}{|c|}{ Relative organ weight ( $\%$ of body weight) } \\
\hline & Liver & Kidney & Pancreas & Liver & Kidney & Pancreas \\
\hline \multicolumn{7}{|l|}{ Controls } \\
\hline Intact & $1.174 \pm 0.063$ & $0.177 \pm 0.008$ & $0.201 \pm 0.023$ & $3.168 \pm 0.373$ & $0.543 \pm 0.040$ & $0.617 \pm 0.073$ \\
\hline HFD & $1.729 \pm 0.109^{\mathrm{a}}$ & $0.245 \pm 0.015^{\mathrm{d}}$ & $0.187 \pm 0.019$ & $3.502 \pm 0.401$ & $0.497 \pm 0.069$ & $0.380 \pm 0.069^{\mathrm{a}}$ \\
\hline \multicolumn{7}{|l|}{ Reference } \\
\hline Metformin & $1.334 \pm 0.134^{\mathrm{a}, \mathrm{c}}$ & $0.206 \pm 0.026^{\mathrm{d}, \mathrm{g}}$ & $0.188 \pm 0.009$ & $3.486 \pm 0.447$ & $0.537 \pm 0.079$ & $0.491 \pm 0.037^{\mathrm{a}, \mathrm{c}}$ \\
\hline \multicolumn{7}{|l|}{ MPh-treated } \\
\hline $500 \mathrm{mg} / \mathrm{kg}$ & $1.140 \pm 0.110^{\mathrm{c}}$ & $0.180 \pm 0.008^{\mathrm{f}}$ & $0.197 \pm 0.019$ & $3.260 \pm 0.256^{\mathrm{b}}$ & $0.515 \pm 0.031$ & $0.566 \pm 0.061^{\mathrm{c}}$ \\
\hline $250 \mathrm{mg} / \mathrm{kg}$ & $1.180 \pm 0.083^{\mathrm{c}}$ & $0.186 \pm 0.008^{\mathrm{e}, \mathrm{f}}$ & $0.192 \pm 0.020$ & $3.357 \pm 0.314$ & $0.530 \pm 0.043$ & $0.546 \pm 0.068^{\mathrm{b}, \mathrm{c}}$ \\
\hline $125 \mathrm{mg} / \mathrm{kg}$ & $1.307 \pm 0.086^{\mathrm{b}, \mathrm{c}}$ & $0.201 \pm 0.010^{\mathrm{d}, \mathrm{f}}$ & $0.188 \pm 0.010$ & $3.476 \pm 0.229$ & $0.534 \pm 0.039$ & $0.501 \pm 0.035^{\mathrm{a}, \mathrm{c}}$ \\
\hline
\end{tabular}

a significant $(\mathrm{p}<0.01)$ increase in relative pancreas weight was noted in the mice treated with metformin at $250 \mathrm{mg} / \mathrm{kg}$ or MPh at 125,250 and $500 \mathrm{mg} / \mathrm{kg}$ compared with the HFD controls. No significant changes were detected in the absolute pancreatic weight in any of the experimental HFD-fed mice, including HFD controls, compared with the intact controls (Table III).

Effects on blood glucose, insulin and HbAlc levels. A significant $(\mathrm{p}<0.01)$ increase in blood glucose levels was noted in the HFD controls compared with the intact controls. However, the blood glucose levels were significantly $(\mathrm{p}<0.01)$ decreased by treatment with metformin or MPh compared with the HFD controls (Fig. 1A). A significant $(\mathrm{p}<0.01)$ increase in serum insulin levels was detected in the HFD controls compared with the intact controls. However, the serum insulin levels were significantly $(\mathrm{p}<0.01)$ decreased by treatment with all test agents compared with the HFD controls (Fig. 1B). In addition, a significant $(\mathrm{p}<0.01)$ increase in the blood HbA1c content was observed in the HFD controls compared with the intact controls. However, the blood HbAlc content was significantly $(\mathrm{p}<0.01)$ decreased by treatment with all test agents compared with the HFD controls (Fig. 1C).

Effects on pancreatic islet hyperplasia and expansion. A significant $(\mathrm{p}<0.01)$ increase in the number and mean diameter of pancreatic islets was detected in the HFD controls compared with the intact controls due to marked hyperplasia of the pancreatic islets themselves or component endocrine cells. However, both hyperplasia and expansion of islets were significantly $(\mathrm{p}<0.01$ or $\mathrm{p}<0.05)$ reduced by treatment with all test agents, including MPh at $125 \mathrm{mg} / \mathrm{kg}$, compared with the HFD controls (Table IV and Fig. 2). 
Table IV. Changes on histopathology-histomorphometry of the pancreas of mice with type II diabetes.

\begin{tabular}{lccccc}
\hline Group & $\begin{array}{c}\text { Zymogen granules } \\
\left(\% / \mathrm{mm}^{2} \text { of exocrine }\right)\end{array}$ & $\begin{array}{c}\text { Mean islet numbers } \\
\left(\text { nos. } / 10 \mathrm{~mm}^{2}\right)\end{array}$ & $\begin{array}{c}\text { Mean islet diameter } \\
(\mu \mathrm{m} / \text { islet })\end{array}$ & $\begin{array}{c}\text { Insulin-IR cells } \\
\left(\text { cells } / \mathrm{mm}^{2}\right)[\mathrm{A}]\end{array}$ & $\begin{array}{c}\text { Glucagon-IR cells Insulin/glucagon } \\
\left(\text { cells } / \mathrm{mm}^{2}\right)[\mathrm{B}]\end{array}$ \\
\hline ratio $[\mathrm{A} / \mathrm{B}]$
\end{tabular}

${ }^{\mathrm{a}} \mathrm{p}<0.01$ and ${ }^{\mathrm{b}} \mathrm{p}<0.05$ as compared with the intact control by LSD test; ${ }^{\mathrm{c}} \mathrm{p}<0.01$ as compared with the high-fat diet (HFD) control by LSD test; ${ }^{\mathrm{d}} \mathrm{p}<0.01$ and ${ }^{\mathrm{e}} \mathrm{p}<0.05$ as compared with intact control by Mann-Whitney $\mathrm{U}(\mathrm{MW})$ test; ${ }^{\mathrm{f}} \mathrm{p}<0.01$ and ${ }^{\mathrm{g}} \mathrm{p}<0.05$ as compared with HFD control by MW test. Values are expressed as the means \pm SD of 8 mice. HFD, $45 \%$ kcal high-fat diet; MPh, melanian snail (Semisulcospira libertina) protein hydrolysates, test material. Metformin was administered at dose levels of $250 \mathrm{mg} / \mathrm{kg}$.
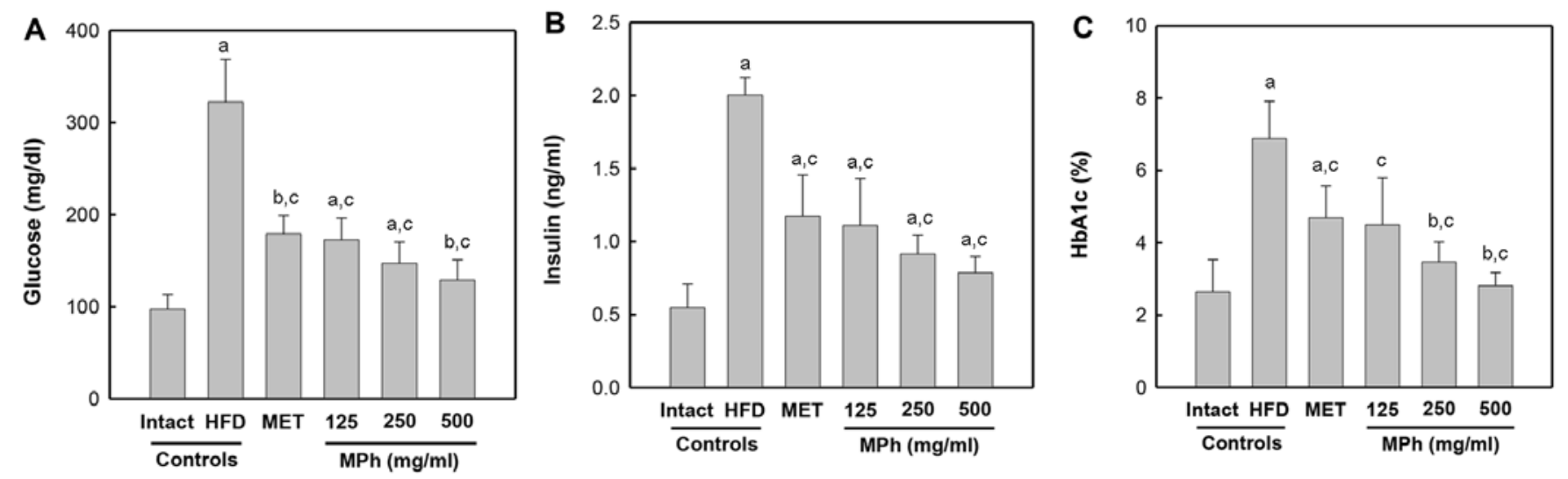

Figure 1. Changes in (A) blood glucose, (B) insulin, and (C) HbAlc levels in mice with type II diabetes. Values are expressed as the means \pm SD of 8 mice. HFD, $45 \% \mathrm{kcal}$ high-fat diet; MPh, melanian snail (Semisulcospira libertina) protein hydrolysates, test material. Metformin was administered at a dose of $250 \mathrm{mg} / \mathrm{kg}$. ${ }^{\mathrm{a}} \mathrm{p}<0.01$ and ${ }^{\mathrm{b}} \mathrm{p}<0.05$ as compared with vthe intact control by Mann-Whitney U (MW) test; ${ }^{\mathrm{c}} \mathrm{p}<0.01$ as compared with the HFD control by MW test.

Effects on pancreatic islet glucagon- and insulin-immunoreactive cells. A significant $(\mathrm{p}<0.01)$ increase in glucagon- and insulin-immunoreactive cells, and in the insulin-immunoreactive/glucagon-immunoreactive cell ratio, was noted in the HFD control mice compared with the intact controls. However, these abnormal increases in insulin- and glucagon-immunoreactive cells and their ratios (insulin-immunoreactive/glucagon-immunoreactive cells) were significantly $(\mathrm{p}<0.01)$ normalized by treatment with all test agents, including $\mathrm{MPh}$ at $250 \mathrm{mg} / \mathrm{kg}$, compared with the HFD controls (Table IV and Fig. 3).

\section{Antihyperlipidemic effects}

Effects on serum TC, TG, $L D L$, and $H D L$ levels. A significant $(\mathrm{p}<0.01)$ increase in serum TC, TG and LDL levels was detected in the HFD controls compared with the intact controls. However, the serum TC, TG and LDL levels were significantly $(p<0.01)$ decreased in all the test agent groups. The mice treated with MPh at 250 or $500 \mathrm{mg} / \mathrm{kg}$ in particular exhibited a marked decrease in TC and TG levels compared with the HFD controls (Table V). In addition, a significant $(\mathrm{p}<0.01)$ decrease in serum HDL levels was noted in the HFD controls compared with the intact controls. However, the serum HDL levels were significantly $(\mathrm{p}<0.01)$ increased in all of the test agent groups (Table V).

Effects on zymogen granule contents of exocrine pancreas. A significant $(\mathrm{p}<0.01)$ decrease in the zymogen granule contents of the exocrine pancreas (percentages of exocrine pancreas occupied by zymogen granules) was identified in the HFD controls compared with the intact controls due to the release of zymogen granules. However, the exocrine pancreas zymogen granule contents significantly $(\mathrm{p}<0.01)$ increased in mice treated with MPh at all concentrations examined compared with the HFD controls (Table IV and Fig. 2).

\section{Effects on glucose-regulating enzymes in the liver}

Effects on hepatic GK activity. A significant $(\mathrm{p}<0.01)$ decrease in the activity of hepatic GK, one of the blood glucose-utilizing hepatic enzymes, was noted in the HFD controls compared with the intact controls; however, these levels were significantly $(\mathrm{p}<0.01)$ normalized by treatment with all test agents compared with the HFD control mice (Table VI). 
Low magnification
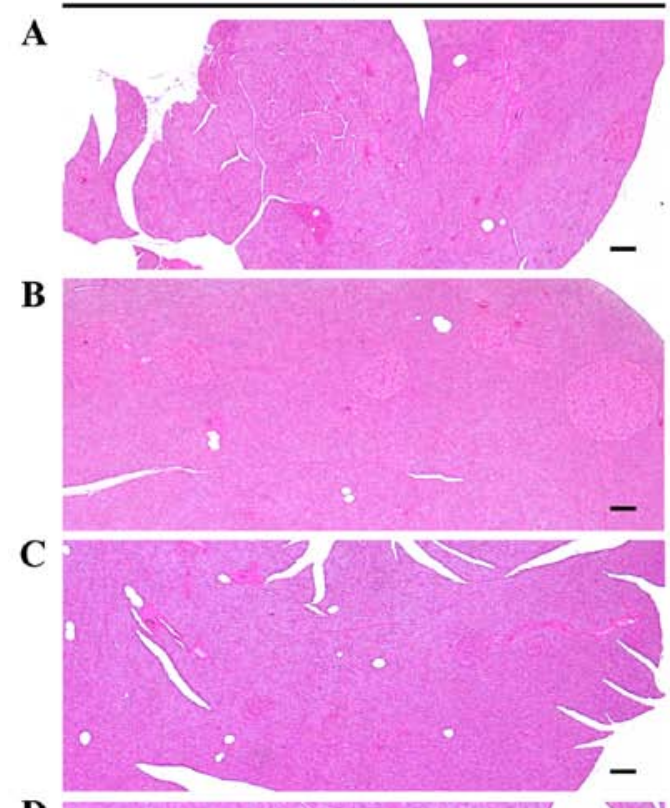

D

$\mathbf{E}$

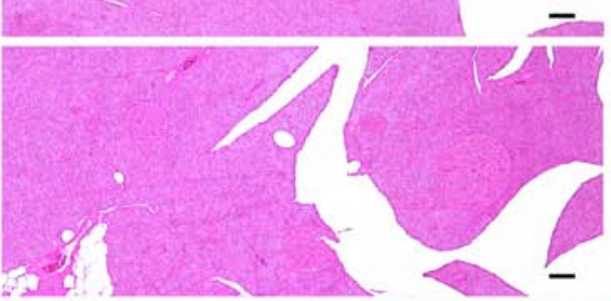

$\mathbf{F}$

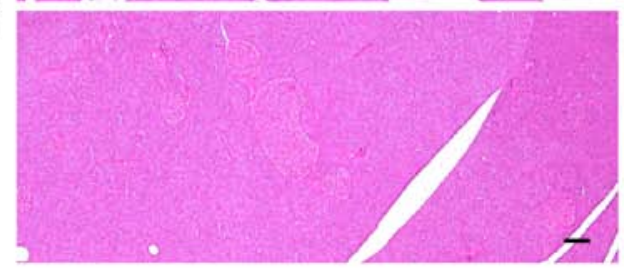

Pancreatic islets
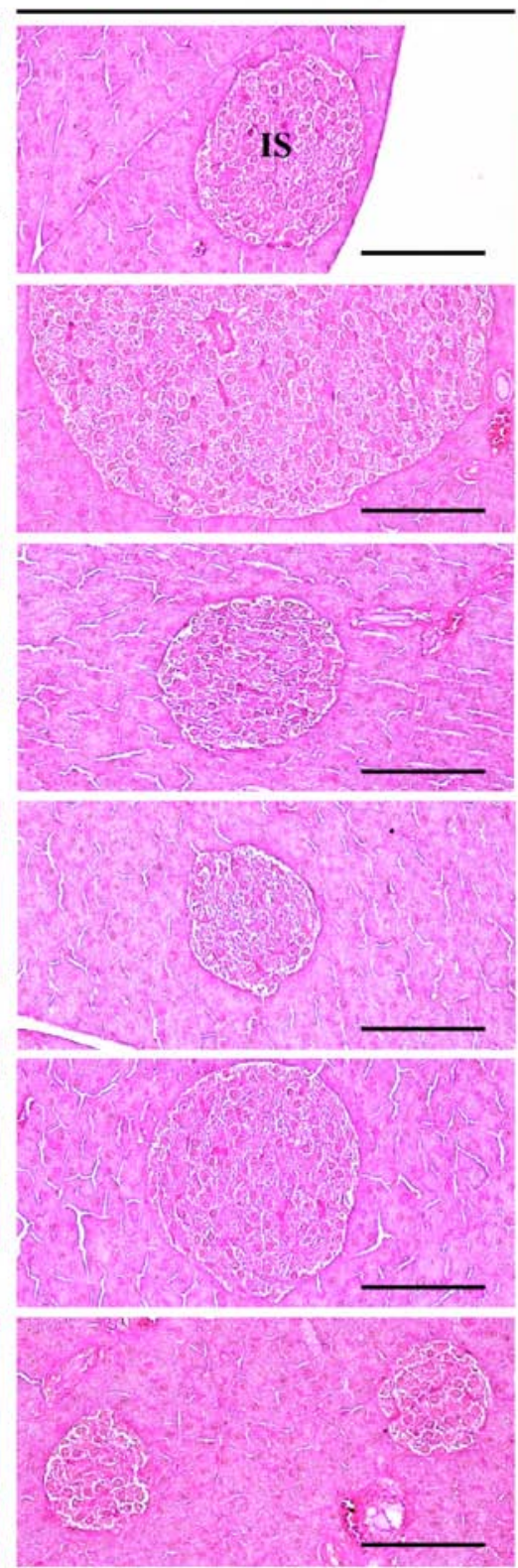

Exocrine zymogen
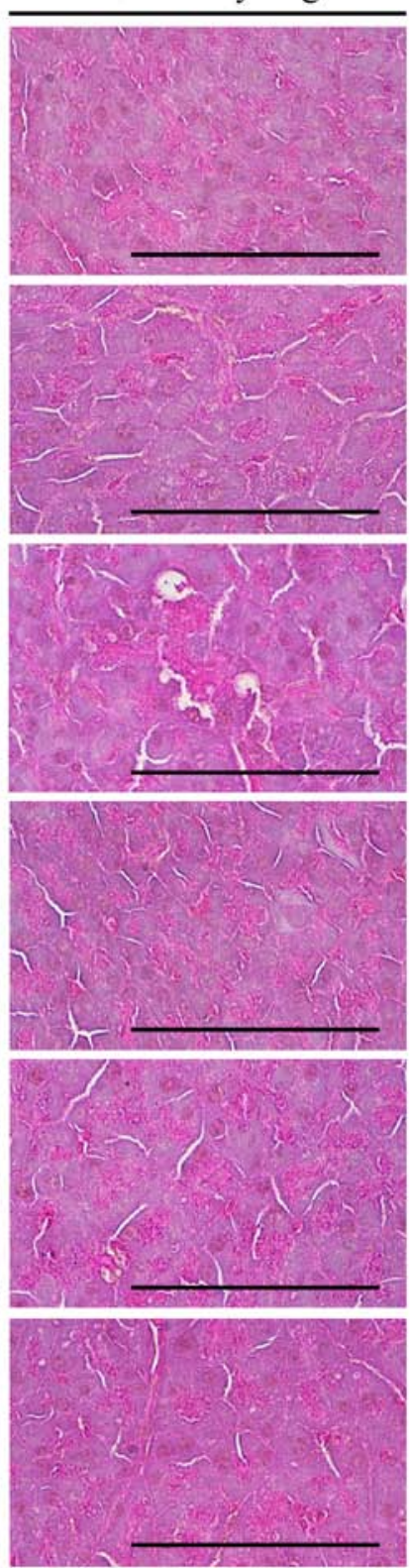

Figure 2. Histological images of the pancreas. Note that the noticeable decrease in the exocrine pancreas zymogen granule content (the percentages of exocrine pancreas occupied by zymogen granules) may be due to the release of zymogen granules, and an increase in pancreatic islet numbers and mean diameters results from marked hyperplasia of the pancreatic islet itself or component endocrine cells detected in the HFD control as compared with the intact control. However, exocrine pancreas zymogen granule contents were markedly increased in all test material-treated mice as compared with the HFD control, in which the percentages of exocrine pancreas occupied by zymogen granules were not significantly altered as compared to those of HFD control mice. In addition, expansions of pancreatic islets were also meaningfully inhibited by treatment with all test materials in the present study. (A) Intact control: mice supplied normal pellet diet (vehicle control mice); mice administered $10 \mathrm{ml} / \mathrm{kg}$ of distilled water orally. (B) HFD control: mice administered $10 \mathrm{ml} / \mathrm{kg}$ of distilled water orally with HFD supply. (C) Metformin, mice administered $250 \mathrm{mg} / \mathrm{kg}$ of metformin orally with HFD supply. (D) MPh 500, mice administered $500 \mathrm{mg} / \mathrm{kg}$ of MPh orally with HFD supply. (E) MPh 250, mice administered $250 \mathrm{mg} / \mathrm{kg}$ of MPh orally with HFD supply. (F) MPh 125, mice administered $125 \mathrm{mg} / \mathrm{kg}$ of MPh orally with HFD supply. HFD, 45\% kcal high-fat diet; MPh, melanian snail (Semisulcospira libertina) protein hydrolysates, test material; IS, pancreatic islet. PD, pancreatic secretory duct. All images show hematoxylin and eosin staining. Scale bars, $80 \mu \mathrm{m}$.

Effects on hepatic G6pase activity. A significant $(\mathrm{p}<0.01)$ increase in the activity of hepatic G6pase, one of the gluconeogenesis hepatic enzymes, was identified in the HFD controls compared with the intact controls; however, these levels were significantly $(\mathrm{p}<0.01)$ normalized by treatment with all test agents compared with the HFD control mice (Table VI).

Effects on hepatic PEPCK activity. A significant $(\mathrm{p}<0.01)$ increase in the activity of hepatic PEPCK, a gluconeogenesis hepatic enzyme, was noted in the HFD controls compared with the intact controls; however, these levels were significantly $(\mathrm{p}<0.01$ or $\mathrm{p}<0.05)$ normalized by treatment with all test agents compared with the HFD control mice (Table VI).

\section{Effects on liver damage}

Effects on liver weight. A significant $(\mathrm{p}<0.01)$ increase in absolute liver weight was observed in the HFD controls compared with the intact controls. However, this increase in absolute liver weight was significantly $(\mathrm{p}<0.01)$ normalized by treatment with 


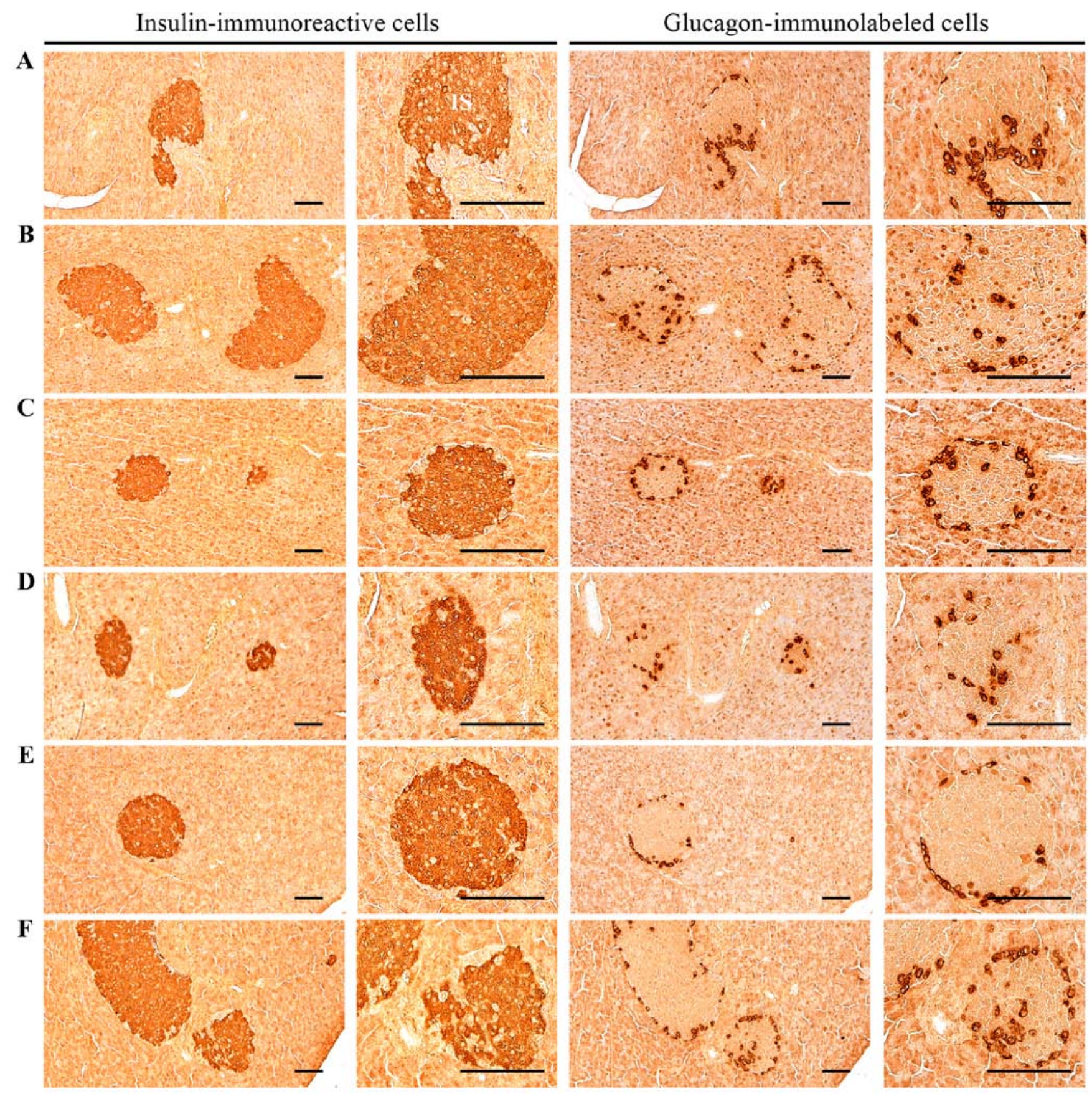

Figure 3. Histological images of the insulin- and glucagon-immunoreactive cells in the pancreas. Significant increases of insulin and glucagon-immunoreactive cells, and also insulin/glucagon cells were detected in the HFD control mice as compared with the intact control. However, these abnormal increases in insulin and glucagon-immunostained cells and their ratio (insulin/glucagon cells) were significantly normalized by treatment with all test materials, including MPh $250 \mathrm{mg} / \mathrm{kg}$ as compared with the HFD control.(A) Intact control: mice supplied normal pellet diet (vehicle control mice); mice administered $10 \mathrm{ml} / \mathrm{kg}$ of distilled water orally. (B) HFD control: mice administered $10 \mathrm{ml} / \mathrm{kg}$ of distilled water orally with HFD supply. (C) Metformin, mice administered $250 \mathrm{mg} / \mathrm{kg}$ of metformin orally with HFD supply. (D) MPh 500 , mice administered $500 \mathrm{mg} / \mathrm{kg}$ of MPh orally with HFD supply. (E) MPh 250, mice administered $250 \mathrm{mg} /$ $\mathrm{kg}$ of MPh orally with HFD supply. (F) MPh 125 , mice administered $125 \mathrm{mg} / \mathrm{kg}$ of MPh orally with HFD supply. HFD, 45\% kcal high-fat diet. MPh, melanian snail (Semisulcospira libertina) protein hydrolysates, test material. All images show immunostaining with avidin-biotin-peroxidase complex. Scale bars, $80 \mu \mathrm{m}$.

all test agents, including MPh at $250 \mathrm{mg} / \mathrm{kg}$, compared with the HFD control mice. No significant changes in relative liver weight were observed in the HFD control mice compared with the intact controls, and mice treated with any of the test agents compared with the HFD controls (Table III).

Effects on serum AST and ALT levels. A significant $(\mathrm{p}<0.01)$ increase in serum AST and ALT levels was observed in the
HFD control mice as compared to the intact controls. However, the serum AST and ALT levels were significantly $(\mathrm{p}<0.01)$ decreased in all the test agent-administered mice (Table VI).

Effects on steatohepatitis and hepatocyte hypertrophy. A significant $(\mathrm{p}<0.01)$ increase in steatohepatitis (percentage change of fatty regions in liver parenchyma) was noted in the HFD controls as compared to the intact controls. This 
Table V. Changes in the levels of secondary liver damage markers in mice with type II diabetes.

\begin{tabular}{|c|c|c|c|c|c|c|c|c|}
\hline Group & $\begin{array}{l}\text { AST } \\
\text { (IU/l) }\end{array}$ & $\begin{array}{l}\text { ALT } \\
\text { (IU/l) }\end{array}$ & $\begin{array}{c}\mathrm{TC} \\
(\mathrm{mg} / \mathrm{dl})\end{array}$ & $\begin{array}{c}\mathrm{TG} \\
(\mathrm{mg} / \mathrm{dl})\end{array}$ & $\begin{array}{c}\text { LDL } \\
\text { cholesterol } \\
(\mathrm{mg} / \mathrm{dl})\end{array}$ & $\begin{array}{c}\text { HDL } \\
\text { cholesterol } \\
(\mathrm{mg} / \mathrm{dl})\end{array}$ & $\begin{array}{l}\text { Liver steatosis } \\
\left(\% / \mathrm{mm}^{2} \text { of }\right. \\
\text { hepatic tissues })\end{array}$ & $\begin{array}{c}\text { Mean } \\
\text { hepatocyte } \\
\text { diameters } \\
(\mu \mathrm{m} / \text { cell })\end{array}$ \\
\hline \multicolumn{9}{|l|}{ Controls } \\
\hline Intact & $75.88 \pm 14.36$ & $36.25 \pm 12.01$ & $118.50 \pm 22.55$ & $52.63 \pm 18.32$ & $15.25 \pm 2.38$ & $107.00 \pm 24.93$ & $7.28 \pm 2.66$ & $17.91 \pm 1.90$ \\
\hline HFD & $230.63 \pm 28.91^{\mathrm{a}}$ & $176.13 \pm 21.12^{\mathrm{a}}$ & $289.75 \pm 30.06^{\mathrm{a}}$ & $218.13 \pm 18.73^{a}$ & $51.00 \pm 8.19^{d}$ & $21.00 \pm 7.89^{\mathrm{a}}$ & $78.95 \pm 11.01^{\mathrm{a}}$ & $55.14 \pm 12.63^{\mathrm{a}}$ \\
\hline \multicolumn{9}{|c|}{ Reference } \\
\hline Metfor & n $152.00 \pm 45.23^{\mathrm{a}, \mathrm{c}}$ & ${ }^{c} 99.63 \pm 19.67^{\mathrm{a}, \mathrm{c}}$ & $207.38 \pm 39.19^{\mathrm{a}, \mathrm{c}}$ & $147.63 \pm 15.65^{\mathrm{acc}}$ & ${ }^{c} 28.88 \pm 8.63^{\mathrm{d}, \mathrm{f}}$ & $58.88 \pm 18.88^{\mathrm{a}, \mathrm{c}}$ & $42.82 \pm 14.23^{\mathrm{a}, \mathrm{c}}$ & $28.71 \pm 1.70^{\mathrm{a}, \mathrm{c}}$ \\
\hline \multicolumn{9}{|c|}{ MPh-treated } \\
\hline $500 \mathrm{mg}$ & g $114.38 \pm 38.44^{\mathrm{b}, \mathrm{c}}$ & $61.63 \pm 15.13^{\mathrm{a}, \mathrm{c}}$ & $151.38 \pm 17.02^{\mathrm{b}, \mathrm{c}}$ & $104.63 \pm 20.83^{\mathrm{a}, \mathrm{c}}$ & c $18.88 \pm 2.10^{\mathrm{d}, \mathrm{f}}$ & $81.13 \pm 12.23^{\mathrm{a}, \mathrm{c}}$ & $=15.07 \pm 3.91^{\mathrm{a}, \mathrm{c}}$ & $20.88 \pm 4.92^{\mathrm{c}}$ \\
\hline $250 \mathrm{mg}$ & g $121.75 \pm 37.92^{\mathrm{b}, \mathrm{c}}$ & c $72.75 \pm 17.65^{\mathrm{a}, \mathrm{c}}$ & $171.13 \pm 20.19^{\mathrm{a}, \mathrm{c}}$ & $=114.63 \pm 27.33^{\mathrm{a}, \mathrm{c}}$ & c $20.50 \pm 2.33^{\mathrm{d}, \mathrm{f}}$ & $76.50 \pm 15.43^{\mathrm{a}, \mathrm{c}}$ & $=19.02 \pm 3.53^{\mathrm{a}, \mathrm{c}}$ & $21.04 \pm 2.52^{\mathrm{b}, \mathrm{c}}$ \\
\hline $125 \mathrm{mg}$ & g $146.13 \pm 38.36^{\mathrm{a}, \mathrm{c}}$ & c $90.13 \pm 17.88^{\mathrm{a}, \mathrm{c}}$ & $192.13 \pm 29.35^{\mathrm{a}, \mathrm{c}}$ & $=139.00 \pm 19.79^{a, c}$ & c $27.50 \pm 5.48^{\mathrm{d}, \mathrm{f}}$ & $68.75 \pm 14.85^{\mathrm{a}, \mathrm{c}}$ & $=37.79 \pm 12.52^{\mathrm{a}, \mathrm{c}}$ & $26.13 \pm 4.18^{\mathrm{a}, \mathrm{c}}$ \\
\hline
\end{tabular}

Table VI. Changes in hepatic glucose-regulating enzyme activities in mice with type II diabetes.

\begin{tabular}{|c|c|c|c|}
\hline Group & $\begin{array}{c}\text { Glucokinase } \\
\text { (nM/min/mg } \\
\text { protein) }\end{array}$ & $\begin{array}{c}\text { Glucose-6- } \\
\text { phosphatase } \\
\text { (nM/min/mg } \\
\text { protein) }\end{array}$ & $\begin{array}{c}\text { PEPCK } \\
\text { (nM/min/mg } \\
\text { protein) }\end{array}$ \\
\hline \multicolumn{4}{|l|}{ Controls } \\
\hline Intact & $2.93 \pm 0.28$ & $106.12 \pm 16.57$ & $1.84 \pm 0.40$ \\
\hline HFD & $1.71 \pm 0.37^{\mathrm{a}}$ & $194.17 \pm 23.69^{\mathrm{a}}$ & $4.91 \pm 0.79^{\mathrm{a}}$ \\
\hline \multicolumn{4}{|l|}{ Reference } \\
\hline Metformin & $2.34 \pm 0.27^{\mathrm{a}, \mathrm{c}}$ & $143.48 \pm 21.87^{\mathrm{a}, \mathrm{c}}$ & $2.99 \pm 0.65^{\mathrm{a}, \mathrm{c}}$ \\
\hline \multicolumn{4}{|l|}{ MPh-treated } \\
\hline $500 \mathrm{mg} / \mathrm{kg}$ & $2.85 \pm 0.32^{c}$ & $120.64 \pm 17.81^{c}$ & $2.40 \pm 0.43^{c}$ \\
\hline $250 \mathrm{mg} / \mathrm{kg}$ & $2.65 \pm 0.46^{\mathrm{c}}$ & $132.41 \pm 21.62^{\mathrm{b}, \mathrm{c}}$ & $2.63 \pm 0.42^{\mathrm{b}, \mathrm{c}}$ \\
\hline $125 \mathrm{mg} / \mathrm{kg}$ & $2.39 \pm 0.42^{\mathrm{a}, \mathrm{c}}$ & $139.86 \pm 26.50^{\mathrm{a}, \mathrm{c}}$ & $2.91 \pm 0.74^{\mathrm{a}, \mathrm{c}}$ \\
\hline \multicolumn{4}{|c|}{$\begin{array}{l}{ }^{\mathrm{a}} \mathrm{p}<0.01 \text { and }{ }^{\mathrm{b}} \mathrm{p}<0.05 \text { as compared with the intact control by LSD test; } \\
{ }^{\mathrm{c}} \mathrm{p}<0.01 \text { as compared with the HFD control by LSD test. Values are } \\
\text { expressed as the means } \pm \text { SD of } 8 \text { mice. HFD, } 45 \% \text { kcal high-fat diet; } \\
\text { MPh, melanian snail (Semisulcospira libertina) protein hydrolysates, test } \\
\text { material; PEPCK, phosphoenolpyruvate carboxykinase. Metformin was } \\
\text { administered at dose levels of } 250 \mathrm{mg} / \mathrm{kg} \text {. }\end{array}$} \\
\hline
\end{tabular}

was perhaps due to the severe hypertrophy of hepatocytes related to intracellular lipid depositions. However, increases in steatohepatitis were significantly $(\mathrm{p}<0.01)$ normalized by treatment with all test agents, including metformin at $250 \mathrm{mg} /$ $\mathrm{kg}$. A significant $(\mathrm{p}<0.01)$ increase in the mean diameter of hepatocytes (hypertrophy) was observed in the HFD controls compared with the intact controls. However, hepatocyte hypertrophy was markedly and significantly $(\mathrm{p}<0.01)$ decreased in all test agent-treated mice, including the $\mathrm{MPh} 125 \mathrm{mg} / \mathrm{kg}$ group, compared with the HFD controls (Table V and Fig. 4).
Effects on kidney damage

Effects on kidney weight. A significant $(\mathrm{p}<0.01)$ increase in absolute kidney weight was observed in the HFD controls compared with the intact controls; this increase was significantly $(p<0.01$ or $p<0.05)$ normalized by treatment with all test agents, including $\mathrm{MPh}$ at $500 \mathrm{mg} / \mathrm{kg}$, compared with the HFD-fed mice. No significant changes in relative kidney weight were noted in the HFD control mice compared with the intact controls, and there were no significant changes in relative kidney weight in mice treated with any of the test agents compared with the HFD control mice (Table III).

Effects on serum BUN and creatinine levels. A significant $(\mathrm{p}<0.01)$ increase in serum BUN levels was observed in the HFD controls compared with the intact controls. However, the serum BUN levels were significantly $(p<0.01)$ decreased in the HFD-fed mice treated with all test agents compared with the HFD controls (Table VII). In addition, a significant $(\mathrm{p}<0.01)$ increase in serum creatinine levels was noted in the HFD control mice compared with intact the controls. However, the serum creatinine levels were significantly $(\mathrm{p}<0.01)$ decreased in all test agent-treated HFD mice, including the MPh group at $500 \mathrm{mg} / \mathrm{kg}$ group, when compared with the HFD controls (Table VII).

Effects on kidney histopathology. A significant $(\mathrm{p}<0.01)$ increase in degenerative vacuolated renal tubules was observed in the HFD control mice compared with the intact controls, which resulted from diabetic nephropathies associated with lipid droplet deposition; however, these diabetic nephropathies were significantly $(\mathrm{p}<0.01)$ normalized by treatment with all test agents in the experiments (Table VII and Fig. 5).

\section{Effects on the antioxidant system of the liver}

Effects on liver lipid peroxidation. A significant $(\mathrm{p}<0.01)$ increase in liver lipid peroxidation and the elevation of hepatic MDA content was noted in the HFD controls compared with the intact controls; however, these increases 
H\&E stain
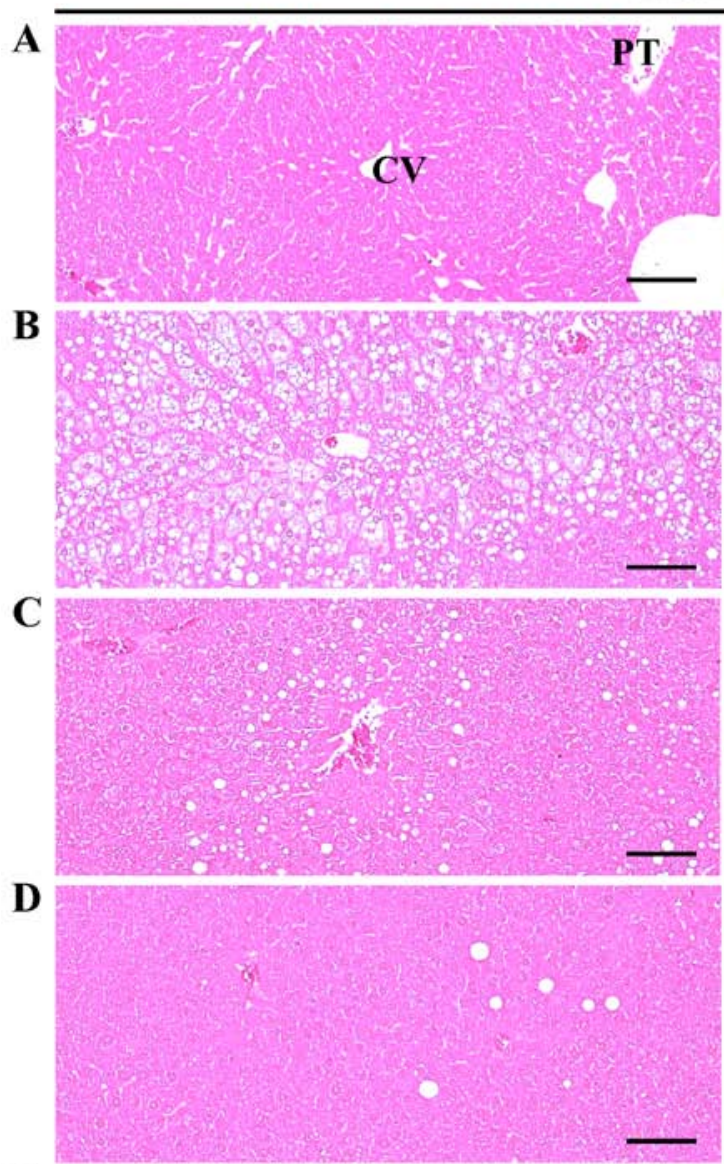

$\mathbf{E}$

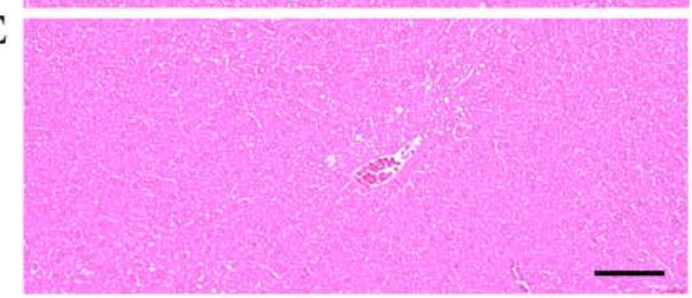

F

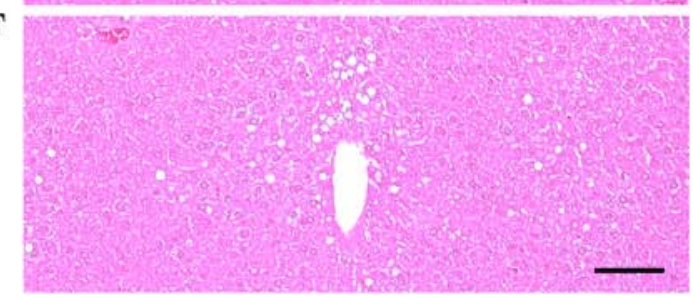

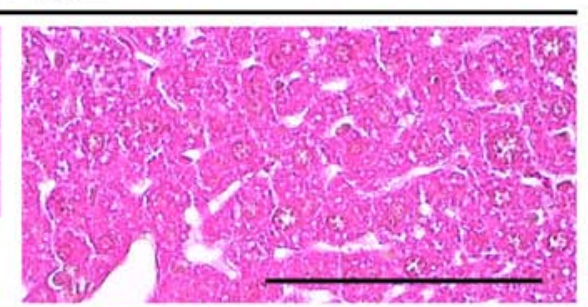
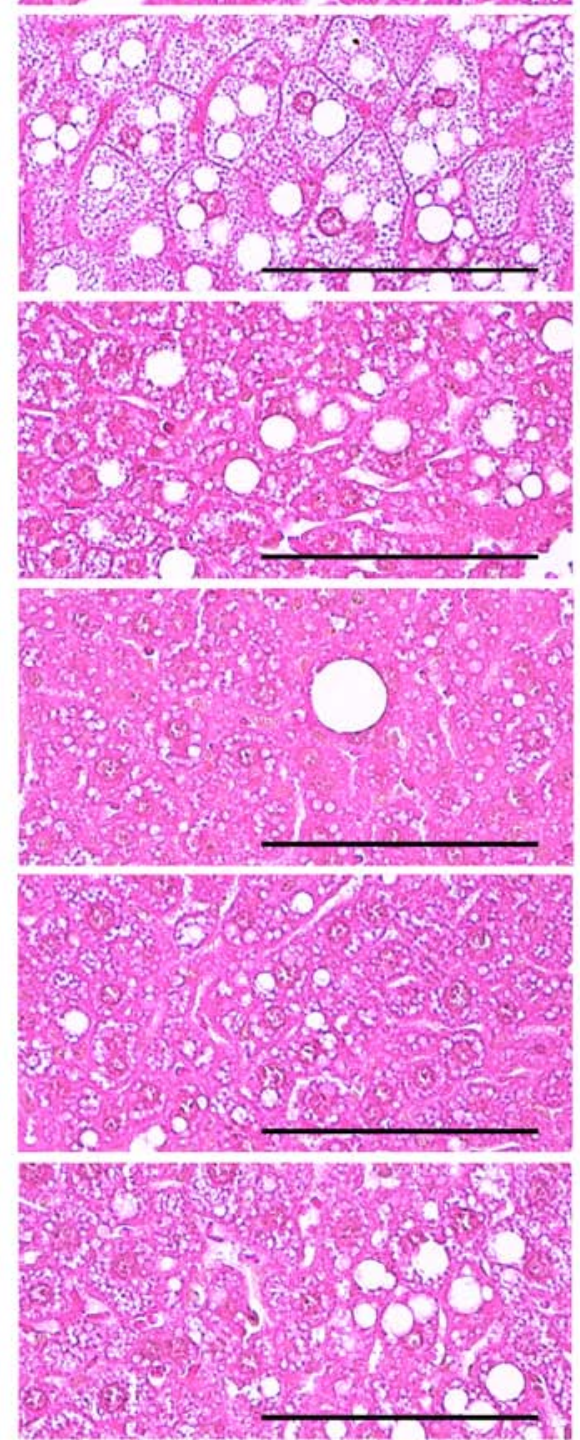

Oil red stain
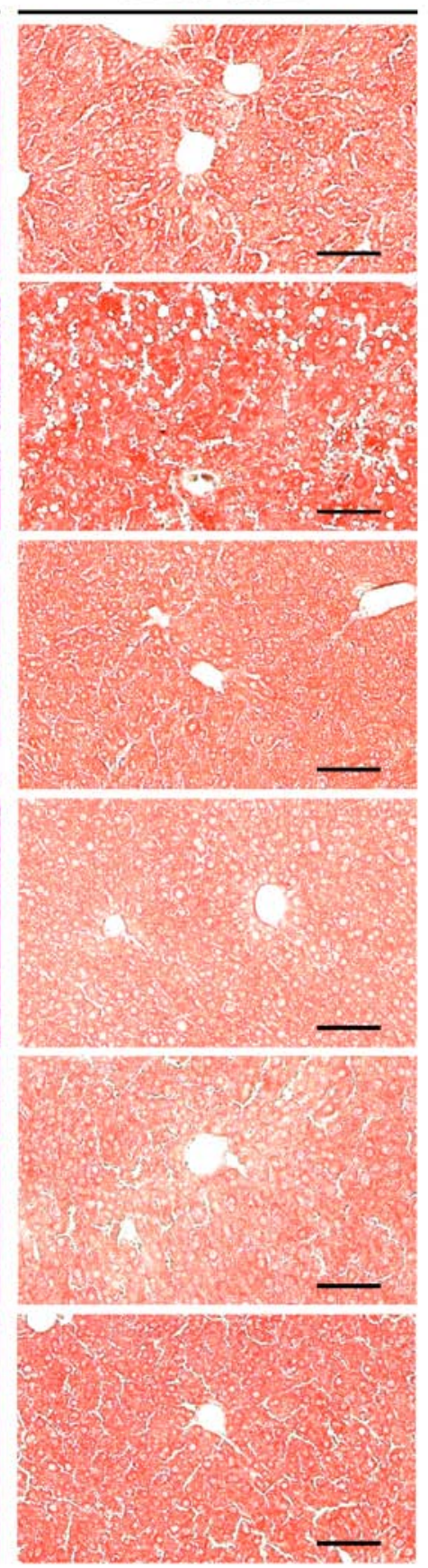

Figure 4. Histological images of the liver. Note that marked increases in steatohepatitis and in the percentages of fatty changed regions in liver parenchyma, were detected in the HFD control as compared with the intact control, resulting from severe hypertrophy of hepatocyte related to intracellular lipid depositions. However, steatohepatitis was normalized by treatment with all test materials, including MPh $250 \mathrm{mg} / \mathrm{kg}$ treated mice. In particular, the HFD-fed mice treated with MPh at 125,250 and $500 \mathrm{~m} / \mathrm{kg}$ also exhibited noticeable decreases in steatohepatitis regions and related hepatocyte hypertrophies as compared with HFD-fed mice, in this experiment. (A) Intact control: mice supplied normal pellet diet (vehicle control mice); mice administered $10 \mathrm{ml} / \mathrm{kg}$ of distilled water orally. (B) HFD control: mice administered $10 \mathrm{ml} / \mathrm{kg}$ of distilled water orally with HFD supply. (C) Metformin, mice administered $250 \mathrm{mg} / \mathrm{kg}$ of metformin orally with HFD supply. (D) MPh 500, mice administered $500 \mathrm{mg} / \mathrm{kg}$ of MPh orally with HFD supply. (E) MPh 250, mice administered $250 \mathrm{mg} / \mathrm{kg}$ of MPh orally with HFD supply. (F) MPh 125, mice administered $125 \mathrm{mg} / \mathrm{kg}$ of MPh orally with HFD supply.. HFD, 45\% kcal high-fat diet; MPh, melanian snail (Semisulcospira libertina) protein hydrolysates, test material; CV, central vein; PT, portal triad. Scale bars, $80 \mu \mathrm{m}$.

were significantly $(\mathrm{p}<0.01)$ normalized by treatment with all test agents, including $\mathrm{MPh}$ at $125 \mathrm{mg} / \mathrm{kg}$, compared with the HFD controls (Table VIII).

Effects on the GSH contents and on hepatic CAT and SOD activities. A significant $(\mathrm{p}<0.01)$ decrease in the hepatic GSH content, and CAT and SOD enzymatic activity, as representa- tive endogenous antioxidants, was observed in the HFD control mice compared with the intact controls. However, the hepatic GSH content was significantly $(\mathrm{p}<0.01)$ increased in all test agent-treated HFD mice (Table VIII). In addition, the decreases in hepatic CAT and SOD activities were significantly $(\mathrm{p}<0.01)$ normalized by treatment with all test agents (Table III). 
Table VII. Changes in the levels of secondary kidney damage markers in mice with type II diabetes.

\begin{tabular}{lccc}
\hline Group & $\begin{array}{c}\text { BUN } \\
(\mathrm{mg} / \mathrm{dl})\end{array}$ & $\begin{array}{c}\text { Creatinine } \\
(\mathrm{mg} / \mathrm{dl})\end{array}$ & $\begin{array}{c}\text { Degenerative renal } \\
\text { tubule numbers }(\%)\end{array}$ \\
\hline Controls & & & \\
Intact & $37.00 \pm 13.05$ & $0.69 \pm 0.20$ & $3.88 \pm 1.89$ \\
HFD & $103.00 \pm 21.67^{\mathrm{a}}$ & $2.25 \pm 0.32^{\mathrm{a}}$ & $75.75 \pm 14.19^{\mathrm{a}}$ \\
Reference & & & \\
Metformin & $68.25 \pm 15.94^{\mathrm{a}, \mathrm{c}}$ & $1.56 \pm 0.32^{\mathrm{a}, \mathrm{c}}$ & $44.63 \pm 15.19^{\mathrm{a}, \mathrm{c}}$ \\
MPh-treated & & & \\
$500 \mathrm{mg} / \mathrm{kg}$ & $41.75 \pm 10.79^{\mathrm{c}}$ & $0.94 \pm 0.12^{\mathrm{b}, \mathrm{c}}$ & $21.00 \pm 3.93^{\mathrm{a}, \mathrm{c}}$ \\
$250 \mathrm{mg} / \mathrm{kg}$ & $57.75 \pm 14.24^{\mathrm{a}, \mathrm{c}}$ & $1.03 \pm 0.18^{\mathrm{a}, \mathrm{c}}$ & $30.13 \pm 6.13^{\mathrm{a}, \mathrm{c}}$ \\
$125 \mathrm{mg} / \mathrm{kg}$ & $66.13 \pm 11.34^{\mathrm{a}, \mathrm{c}}$ & $1.43 \pm 0.33^{\mathrm{a}, \mathrm{c}}$ & $41.75 \pm 9.32^{\mathrm{a}, \mathrm{c}}$ \\
\hline
\end{tabular}

Values are expressed as the means \pm SD of 8 mice. HFD, $45 \% \mathrm{kcal}$ high-fat diet; MPh, melanian snail (Semisulcospira libertina) protein hydrolysates, test material. Metformin was administered at dose levels of $250 \mathrm{mg} / \mathrm{kg}$. ${ }^{a} \mathrm{p}<0.01$ and ${ }^{\mathrm{b}} \mathrm{p}<0.05$ as compared with the intact control by Mann-Whitney $\mathrm{U}$ (MW) test; ${ }^{c} \mathrm{p}<0.01$ as compared with the HFD control by MW test

\section{Discussion}

Diabetes mellitus is a major human health concern due to its increasing prevalence, debilitating complications and chronic course (44). The inhibition of oxidative stress and postprandial hyperglycemia are considered important for the treatment of diabetes $(40,44)$. There has been a great deal of research aiming to identify safe and effective $\alpha$-glucosidase inhibitors and antioxidants from natural materials to develop compounds or physiological functional foods for the treatment of diabetes $(10,11,25,26,40)$. The present study was performed to examine the pharmacological activities of $\mathrm{MPh}$ in mice fed a HFD, leading to mild diabetes and obesity $(25,28,45,46)$. Metformin, a representative anti-diabetic drug used in the treatment of type II diabetes $(47,48)$, was used as a potent reference agent.

HFD-fed animals exhibit mild obesity and hyperglycemia; therefore, models using these animals are appropriate for the development of preventive agents for metabolic syndromes (48). In the present study, the HFD control mice exhibited a significant increase in body weight as compared to the intact mice 1 week after the commencement of HFD feeding; accordingly, body weight gains during the 7-day HFD adaptation period and 84-day administration period were also significantly increased compared with the intact controls. However, these increases in body weight were significantly and dose-dependently inhibited by treatment with MPh at 125,250 and $500 \mathrm{mg} / \mathrm{kg}$, and also by metformin at $250 \mathrm{mg} / \mathrm{kg}$.

The energy content of the HFD $(4.73 \mathrm{kcal} / \mathrm{kg})$ was much higher (approximately 20-fold) (Table I) than that of the normal diet $(0.21 \mathrm{kcal} / \mathrm{g})$; hence, the decrease in mean daily food consumption observed in all the diabetic mice compared with the intact controls was considered not to be a critical issue. A similar decrease has previously been reported in the daily food consumption of HFD-fed mice $(26,40)$. In the present study, no significant changes in the levels of mean daily food consumption were detected in any of the test agent-administered groups compared with the HFD controls, suggesting that the pharmacological effects of the test agents detected in this study were unlikely to have been due to the inhibition of food consumption.

Marked increases in blood glucose, insulin and $\mathrm{HbA1c}$ levels, together with increases in insulin- and glucagon-immunoreactive cells, pancreatic islet numbers and diameters, and the insulin/glucagon cell ratio upon histopathological observation, were detected in the HFD control mice compared with the intact controls, similar to the insulin resistance observed in type II diabetes. However, all three doses of MPh effectively and dose-dependently inhibited these increases in insulin,

Table VIII. Changes in liver lipid peroxidation and antioxidant defense systems in mice with type II diabetes.

\begin{tabular}{|c|c|c|c|c|}
\hline \multirow[b]{2}{*}{ Group } & \multirow{2}{*}{ 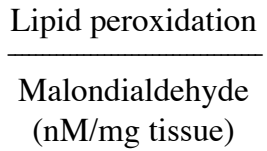 } & \multicolumn{3}{|c|}{ Antioxidant defense system } \\
\hline & & $\begin{array}{c}\text { Glutathione } \\
(\mu \mathrm{M} / \mathrm{mg} \text { tissue })\end{array}$ & $\begin{array}{c}\text { Catalase } \\
\text { (U/mg tissue) }\end{array}$ & $\begin{array}{c}\text { SOD } \\
\text { (U/mg tissue) }\end{array}$ \\
\hline \multicolumn{5}{|l|}{ Controls } \\
\hline Intact & $11.93 \pm 1.66$ & $37.49 \pm 8.75$ & $32.58 \pm 7.24$ & $3.47 \pm 0.85$ \\
\hline HFD & $32.31 \pm 6.27^{\mathrm{a}}$ & $10.38 \pm 1.29^{c}$ & $9.94 \pm 2.65^{\mathrm{c}}$ & $0.82 \pm 0.09^{\mathrm{c}}$ \\
\hline \multicolumn{5}{|l|}{ Reference } \\
\hline Metformin & $24.58 \pm 5.28^{\mathrm{a}, \mathrm{b}}$ & $18.44 \pm 2.95^{\mathrm{c}, \mathrm{e}}$ & $16.90 \pm 1.61^{\mathrm{c}, \mathrm{e}}$ & $1.71 \pm 0.52^{\mathrm{c}, \mathrm{e}}$ \\
\hline \multicolumn{5}{|l|}{ MPh-treated } \\
\hline $500 \mathrm{mg} / \mathrm{kg}$ & $15.56 \pm 3.06^{\mathrm{b}}$ & $28.67 \pm 5.68^{\mathrm{d}, \mathrm{e}}$ & $23.69 \pm 4.11^{\mathrm{d}, \mathrm{e}}$ & $2.20 \pm 0.39^{\mathrm{c}, \mathrm{e}}$ \\
\hline $250 \mathrm{mg} / \mathrm{kg}$ & $17.98 \pm 1.61^{\mathrm{a}, \mathrm{b}}$ & $23.85 \pm 3.93^{\mathrm{c}, \mathrm{e}}$ & $19.71 \pm 1.89^{\mathrm{c}, \mathrm{e}}$ & $2.02 \pm 0.21^{\mathrm{c}, \mathrm{e}}$ \\
\hline $125 \mathrm{mg} / \mathrm{kg}$ & $23.32 \pm 5.01^{\mathrm{a}, \mathrm{b}}$ & $19.84 \pm 3.49^{\mathrm{c}, \mathrm{e}}$ & $17.13 \pm 3.00^{\mathrm{c}, \mathrm{e}}$ & $1.78 \pm 0.34^{\mathrm{c}, \mathrm{e}}$ \\
\hline
\end{tabular}

${ }^{\mathrm{a}} \mathrm{p}<0.01$ as compared with the intact control by LSD test; ${ }^{\mathrm{b}} \mathrm{p}<0.01$ as compared with the HFD control by LSD test; ${ }^{\mathrm{c}} \mathrm{p}<0.01$ and ${ }^{\mathrm{d}} \mathrm{p}<0.05$ as compared with intact control by MW test; ${ }^{\mathrm{p}} \mathrm{p}<0.01$ as compared with HFD control by Mann-Whitney U (MW) test. Values are expressed as the mean \pm SD of 8 mice. HFD, 45\% kcal high-fat diet; MPh, melanian snail (Semisulcospira libertina) protein hydrolysates, test material; SOD, superoxide dismutase. Metformin was administered at dose levels of $250 \mathrm{mg} / \mathrm{kg}$. 


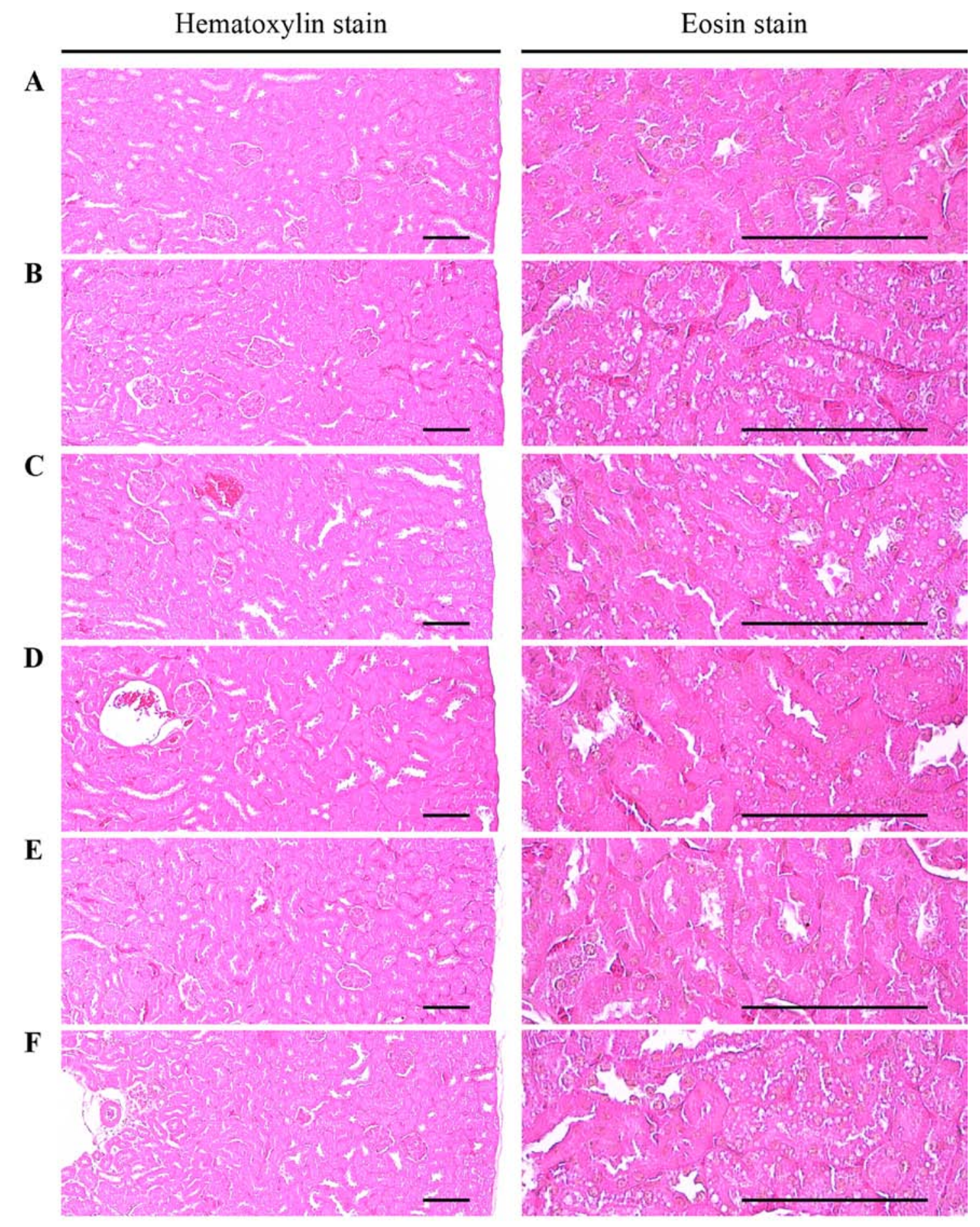

Figure 5. Histological images of the kidney revealed that significant increases in degenerative vacuolated renal tubules were detected in the HFD control as compared with the intact control, resulting from lipid droplet deposited diabetic nephropathies; however, these diabetic nephropathies were significantly normalized by treatment with all test materials as compared with the HFD control, in our experiment. (A) Intact control: mice supplied normal pellet diet (vehicle control mice); mice administered $10 \mathrm{ml} / \mathrm{kg}$ of distilled water orally. (B) HFD control: mice administered $10 \mathrm{ml} / \mathrm{kg}$ of distilled water orally with HFD supply. (C) Metformin, mice administered $250 \mathrm{mg} / \mathrm{kg}$ of metformin orally with HFD supply. (D) MPh 500, mice administered $500 \mathrm{mg} / \mathrm{kg}$ of MPh orally with HFD supply. (E) MPh 250, mice administered $250 \mathrm{mg} / \mathrm{kg}$ of MPh orally with HFD supply. (F) MPh 125, mice administered $125 \mathrm{mg} / \mathrm{kg}$ of MPh orally with HFD supply. HFD, $45 \% \mathrm{kcal}$ high-fat diet; MPh, melanian snail (Semisulcospira libertina) protein hydrolysates, test material. All images show hematoxylin and eosin staining. Scale bars, $80 \mu \mathrm{m}$.

HbA1c content and blood glucose levels, as well as abnormal endocrine histopathological changes in the pancreas (Table IV and Fig. 1). HbAlc is a form of hemoglobin that is measured primarily to identify the average plasma glucose concentration over prolonged periods, and is produced by erythrocytes with long-term exposure to high levels of glucose $(49,50)$. It has been reported that the hyperglycemia, a main sign of diabetes, should be controlled to treat the disease $(25,26,40,51)$. The HFD-fed mouse has been used as an animal model of type II diabetes and also exhibits noticeable hyperglycemia $(25,26,45,46,52)$. 
Long-term HFD feeding revealed the characteristics of type II diabetes, altered Hb1Ac levels and marked elevations in the blood (27,28). In addition, increased insulin secretion is related to pancreatic islet hyperplasia commensurate with the progression of insulin resistance caused by HFD feeding (53-55). In previous studies, insulin-producing cells and total pancreatic islet numbers were increased after chronic consumption of HFD, with the islets increasing in area and number to secrete more insulin for maintenance of glucose homeostasis (56), followed by noticeable hypertrophy or hyperplasia of endocrine pancreas cells (53-56). These findings directly indicate that MPh exerts obvious hypoglycemic effects in mice, possibly through the inhibition of pancreatic endocrine changes.

Hyperlipidemia also generally occurs with the chronic progression of diabetes in HFD-fed mice (44). As the most critical issues in hyperlipidemia are the increases in serum TG, TC and LDL levels with decreased HDL levels $(25,26,57)$ the efficacy of hypolipidemic agents is generally evaluated based on decreases in serum TC, TG and LDL along with increases in HDL levels $(25,26,40,58)$. In the present study, all doses of MPh effectively and dose-dependently decreased the serum TC, LDL and TG levels, while increasing serum HDL levels compared with the HFD control mice, suggesting that $\mathrm{MPh}$ exerts favorable hypolipidemic effects on HFD-fed mice. In particular, in this study, MPh at $125 \mathrm{mg} / \mathrm{kg}$ exerted hypolipidemic effects comparable to those of metformin at $250 \mathrm{mg} /$ $\mathrm{kg}$ on HFD-fed mice. In addition, it has been reported that HFD feeding results in the development of acinar cell atrophy, pancreatic steatosis and a decrease in the number of zymogen granules $(40,59,60)$. Increases in the numbers f zymogen granules in exocrine pancreatic acinar cells indicate the production of digestive enzymes, particularly for digestion of proteins and lipids (61). In the present study, a reduction in the number of pancreatic zymogen granules was also detected histopathologically in the HFD-fed control group compared with the intact controls. However, these reductions in zymogen deposition in the exocrine pancreas were effectively inhibited, in a dosedependent manner, by metformin at $250 \mathrm{mg} / \mathrm{kg}$ and also by treatment with MPh at 125,250 and $500 \mathrm{mg} / \mathrm{kg}$. These results may have direct evidence for the anti-hyperlipidemic effects of $\mathrm{MPh}$ in mice, which could be mediated by inhibition of lipid digestion caused by decrease in pancreatic enzyme release or production. As we could not completely exclude the possibility that MPh induced increases in digestive tract motility, further detailed studies are required to elucidate the precise mechanisms of action of MPh.

The hepatic enzyme, GK, is related to glucose homeostasis and its increased expression, which could cause an increase in blood glucose utilization for energy production or glycogen storage in the liver, leading to a reduction in blood glucose levels $(62,63)$. By contrast, the enzymes, PEPCK and G6pase, are associated with hepatic glucose output and gluconeogenesis and increases in their activities are correlated with elevated glucose levels $(64,65)$. Generally, noticeable decreases in hepatic GK activities, and increases in PEPCK and G6pase activities, are observed with HFD feeding (27), and were also observed in the HFD control mice in this study. All three doses of MPh effectively inhibited HFD-induced hepatic glucose-regulating enzyme activity changes in a dose-dependent manner. These results were considered direct evidence that MPh has favorable effects on the activities of hepatic glucose-regulating enzymes and, by extension, on the control of blood glucose levels.

With the progression of diabetes, increases in liver weight due to abnormal glycosylation-related hepatosteatosis, fibrosis and/or hepatocyte hypertrophic changes were observed, with elevation of serum ALT and AST levels $(26,40,66)$. These phenomena have been regarded as diabetic hepatopathy, and were observed previously in HFD-fed mice $(26,67)$. Improvements in these abnormal changes have been considered as direct evidence for the improvement of diabetic hepatopathy (66). In this study, all three doses of MPh effectively and dose-dependently decreased diabetic hepatopathy compared with HFD control mice, suggesting that they had favorable hepatoprotective effects. In addition, increases in kidney weight due to inflammation, necrotic processes and swelling were observed with the elevation of creatinine and serum BUN levels in chronic diabetes. The attenuation of these abnormal changes are considered as direct evidence of the amelioration of diabetic nephropathy $(26,40)$. In this study, HFD-fed mice exhibited a marked increase in absolute kidney weight, elevated creatinine and serum BUN levels, and lipid droplet deposition-related renal tubule vacuolation upon histopathological observations. This suggests mild diabetic nephropathy; however, these levels were normalized by treatment with metformin and all three doses of $\mathrm{MPh}$, representing direct evidence of the favorable nephroprotective effects of these agents.

There is considerable evidence of the roles of free radicals in altered antioxidant defenses in diabetes and the etiology of diabetes (68). Oxidative stress has been reported to play an important role in diabetes mellitus. The generation of free radicals by hyperglycemia is related to glucose autooxidation. Glucose autooxidation has been linked to non-enzymatic glycosylation, and glycosylated proteins have been reported to be a source of free radicals [reactive oxygen species (ROS)] $(40,69)$. In addition, various toxic products of lipid peroxidation damage the surrounding tissues (70). Elevated lipid peroxidation, observed in various organs in HFD-fed mice, also acts as a potent redox cycler by generating harmful ROS and causing organ damage $(71,72)$. Oxidative stress in diabetes co-exists with a decrease in the antioxidant status (73), which can increase the deleterious effects of free radicals. The generation of ROS-related oxidative stress also plays an important role in the etiology of diabetic complications (74). Therefore, the endogenous antioxidant content, the degree of lipid peroxidation, GSH and activities of the antioxidative enzymes, CAT and SOD, in the liver tissue are of secondary importance to improve diabetes and various related complications $(75,76)$. GSH is a representative endogenous antioxidant that prevents tissue damage by maintaining ROS at low levels (at certain cellular concentrations), and is accepted as a protective endogenous antioxidant factor in tissues (77). CAT is an enzyme that catalyzes the conversion of $\mathrm{H}_{2} \mathrm{O}_{2}$ to $\mathrm{H} 2 \mathrm{O}$ and SOD is an antioxidant enzyme that contributes to enzymatic defense mechanisms (78). The depletion of GSH content, the marked elevation of hepatic lipid peroxidation and decreases in CAT and SOD activities were noted in HFD controls in the present study $(25,79)$. However, MPh at 125, 250 and $500 \mathrm{mg} / \mathrm{kg}$ dose-dependently and effectively inhibited the deterioration of hepatic antioxidant defense systems compared with the HFD control mice, suggesting favorable antioxidant effects of MPh in mice. 
In this study, MPh exerted potent anti-diabetic and ameliorating effects on mice with diabetic complications, through the increased modulation of antioxidant defense systems, hepatic glucose-regulating enzyme activities and pancreatic lipid digestion enzymes. The overall effects of MPh at $125 \mathrm{mg} /$ $\mathrm{kg}$ on HFD-induced diabetes and related complications were similar or more potent than those of metformin at $250 \mathrm{mg} / \mathrm{kg}$. Therefore, MPh is a promising, potent and novel medicinal food or ingredient for the treatment of type II diabetes and its related complications.

\section{Acknowledgements}

This study was a component of the project (no. 20130285) entitled 'Development of high value material and bioactive components from freshwater fish', funded by the Ministry of Oceans and Fisheries, Republic of Korea.

\section{References}

1. James PT, Leach R, Kalamara E and Shayeghi M: The worldwide obesity epidemic. Obes Res 9 (Suppl 4): 228S-233S, 2001.

2. Ahmadian M, Wang Y and Sul HS: Lipolysis in adipocytes. Int J Biochem Cell Biol 42: 555-559, 2010.

3. Zimmet P: The burden of type 2 diabetes: are we doing enough? Diabetes Metab 29: 6S9-18, 2003.

4. Lafontan $\mathrm{M}$ and Langin D: Lipolysis and lipid mobilization in human adipose tissue. Prog Lipid Res 48: 275-297, 2009.

5. Lebovitz HE: Insulin resistance: Definition and consequences. Exp Clin Endocrinol Diabetes 109 (Suppl 2): S135-S148, 2001.

6. Goldstein BJ: Insulin resistance as the core defect in type 2 diabetes mellitus. Am J Cardiol 90: 3G-10G, 2002.

7. Angulo P: Nonalcoholic fatty liver disease. N Engl J Med 346: $1221-1231,2002$

8. Kadowaki $\mathrm{T}$ and Yamauchi T: Adiponectin and adiponectin receptors. Endocr Rev 26: 439-451, 2005.

9. Chen H, Qu Z, Fu L, Dong P and Zhang X: Physicochemical properties and antioxidant capacity of 3 polysaccharides from green tea, oolong tea, and black tea. J Food Sci 74: C469-C474, 2009.

10. Hays NP, Galassetti PR and Coker RH: Prevention and treatment of type 2 diabetes: Current role of lifestyle, natural product, and pharmacological interventions. Pharmacol Ther 118: 181-191, 2008.

11. Kwon YI, Apostolidis E and Shetty K: In vitro studies of eggplant (Solanum melongena) phenolics as inhibitors of key enzymes relevant for type 2 diabetes and hypertension. Bioresour Technol 99: 2981-2988, 2008.

12. Davidson MB and Peters AL: An overview of metformin in the treatment of type 2 diabetes mellitus. Am J Med 102: 99-110, 1997.

13. Khurana R and Malik IS: Metformin: Safety in cardiac patients. Heart 96: 99-102, 2010.

14. Manninen AH: Protein hydrolysates in sports nutrition. Nutr Metab (Lond) 6: 38, 2009.

15. Nesse KO, Nagalakshmi AP, Marimuthu P and Singh M: Efficacy of a fish protein hydrolysate in malnourished children. Indian J Clin Biochem 26: 360-365, 2011.

16. López-Barrios L, Gutiérrez-Uribe JA and Serna-Saldívar SO: Bioactive peptides and hydrolysates from pulses and their potential use as functional ingredients. J Food Sci 79: R273-R283, 2014.

17. Ryan JT, Ross RP, Bolton D, Fitzgerald GF and Stanton C: Bioactive peptides from muscle sources: Meat and fish. Nutrients 3: 765-791, 2011.

18. Kim KM, Chang UJ, Kang DH, Kim JM, Choi YM and Suh HJ: Yeast hydrolysate reduces body fat of dietary obese rats. Phytother Res 18: 950-953, 2004.

19. Wergedahl H, Gudbrandsen OA, Røst TH and Berge RK: Combination of fish oil and fish protein hydrolysate reduces the plasma cholesterol level with a concurrent increase in hepatic cholesterol level in high-fat-fed Wistar rats. Nutrition 25: 98-104, 2009.

20. Liu X, Zhang M, Zhang C and Liu C: Angiotensin converting enzyme (ACE) inhibitory, antihypertensive and antihyperlipidaemic activities of protein hydrolysates from Rhopilema esculentum. Food Chem 134: 2134-2140, 2012.
21. Mun JM, Ok HM and Kwon O: Corn gluten hydrolysate and capsaicin have complimentary actions on body weight reduction and lipid-related genes in diet-induced obese rats. Nutr Res 34: 458-465, 2014.

22. Yokogawa S, Cort WW and Yokogawa M: Paragonimus and paragonimiasis. Exp Parasitol 10: 81-137, 1960.

23. Yokogawa S, Cort WW and Yokogawa M: Paragonimus and paragonimiasis. Exp Parasitol 10: 139-205, 1960.

24. Park GM, Kim JJ, Chung PR, Wang Y and Min DY: Karyotypes on three species of Chinese mesogastropod snails, Semisulcospira libertina, S. dolichostoma and Viviparus rivularis. Korean J Parasitol 37: 5-11, 1999.

25. Jung YM, Lee SH, Lee DS, You MJ, Chung IK, Cheon WH, Kwon YS, Lee YJ and Ku SK: Fermented garlic protects diabetic, obese mice when fed a high-fat diet by antioxidant effects. Nutr Res 31: 387-396, 2011.

26. Kim CM, Yi SJ, Cho IJ and Ku SK: Red-koji fermented red ginseng ameliorates high fat diet-induced metabolic disorders in mice. Nutrients 5: 4316-4332, 2013.

27. Chung SI, Rico CW and Kang MY: Comparative study on the hypoglycemic and antioxidative effects of fermented paste (doenjang) prepared from soybean and brown rice mixed with rice bran or red ginseng marc in mice fed with high fat diet. Nutrients 6: 4610-4624, 2014.

28. Kim UH, Yoon JH, Li H, Kang JH, Ji HS, Park KH, Shin DH, Park HY and Jeong TS: Pterocarpan-enriched soy leaf extract ameliorates insulin sensitivity and pancreatic $\beta$-cell proliferation in type 2 diabetic mice. Molecules 19: 18493-18510, 2014.

29. Kavutcu M, Canbolat O, Oztürk S, Olcay E, Ulutepe S, Ekinci C, Gökhun IH and Durak I: Reduced enzymatic antioxidant defense mechanism in kidney tissues from gentamicin-treated guinea pigs: Effects of vitamins E and C. Nephron 72: 269-274, 1996.

30. Jamall IS and Smith JC: Effects of cadmium on glutathione peroxidase, superoxide dismutase, and lipid peroxidation in the rat heart: A possible mechanism of cadmium cardiotoxicity. Toxicol Appl Pharmacol 80: 33-42, 1985.

31. Lowry OH, Rosebrough NJ, Farr AL and Randall RJ: Protein measurement with the Folin phenol reagent. J Biol Chem 193: 265-275, 1951.

32. Sedlak J and Lindsay RH: Estimation of total, protein-bound, and nonprotein sulfhydryl groups in tissue with Ellman's reagent. Anal Biochem 25: 192-205, 1968.

33. Aebi H: Catalase. In: Methods in Enzymatic Analysis. Bergmeyer HU (ed). Academic Press, New York, pp673-686, 1974.

34. Sun Y, Oberley LW and Li Y: A simple method for clinical assay of superoxide dismutase. Clin Chem 34: 497-500, 1988.

35. Hulcher FH and Oleson WH: Simplified spectrophotometric assay for microsomal 3-hydroxy-3-methylglutaryl CoA reductase by measurement of coenzyme A. J Lipid Res 14: 625-631, 1973.

36. Davidson AL and Arion WJ: Factors underlying significant underestimations of glucokinase activity in crude liver extracts: Physiological implications of higher cellular activity. Arch Biochem Biophys 253: 156-167, 1987.

37. Alegre M, Ciudad CJ, Fillat C and Guinovart JJ: Determination of glucose-6-phosphatase activity using the glucose dehydrogenase-coupled reaction. Anal Biochem 173: 185-189, 1988.

38. Bentle LA and Lardy HA: Interaction of anions and divalent metal ions with phosphoenolpyruvate carboxykinase. J Biol Chem 251: 2916-2921, 1976.

39. Kawakami S, Han KH, Nakamura Y, Shimada K, Kitano T, Aritsuka T, Nagura T, Ohba K, Nakamura K and Fukushima M: Effects of dietary supplementation with betaine on a nonalcoholic steatohepatitis (NASH) mouse model. J Nutr Sci Vitaminol (Tokyo) 58: 371-375, 2012.

40. Kang SJ, Lee JE, Lee EK, Jung DH, Song CH, Park SJ, Choi SH, Han $\mathrm{CH}, \mathrm{Ku}$ SK and Lee YJ: Fermentation with Aquilariae Lignum enhances the anti-diabetic activity of green tea in type II diabetic $\mathrm{db} / \mathrm{db}$ mouse. Nutrients 6: 3536-3571, 2014.

41. Lee HS, Chang JH and Ku SK: An immunohistochemical study of the pancreatic endocrine cells of the ddN mouse. Folia Histochem Cytobiol 48: 387-393, 2010.

42. Levene A: Pathological factors influencing excision of tumours in the head and neck. Part I. Clin Otolaryngol Allied Sci 6: 145-151, 1981.

43. Ludbrook J: Update: Microcomputer statistics packages. A personal view. Clin Exp Pharmacol Physiol 24: 294-296, 1997.

44. Chen X, Osborne MC, Rybczynski PJ, Zeck R, Yang M, Xu J, Zhou L, Cryan E, Tang Y and Demarest KT: Pharmacological profile of a novel, non-TZD PPARgamma agonist. Diabetes Obes Metab 7: 536-546, 2005. 
45. Yun SN, Moon SJ, Ko SK, Im BO and Chung SH: Wild ginseng prevents the onset of high-fat diet induced hyperglycemia and obesity in ICR mice. Arch Pharm Res 27: 790-796, 2004.

46. Lee JW, Lee KW, Lee SW, Kim IH and Rhee C: Selective increase in pinolenic acid (all-cis-5,9,12-18:3) in Korean pine nut oil by crystallization and its effect on LDL-receptor activity. Lipids 39: 383-387, 2004.

47. Seufert J, Lübben G, Dietrich K and Bates PC: A comparison of the effects of thiazolidinediones and metformin on metabolic control in patients with type 2 diabetes mellitus. Clin Ther 26: 805-818, 2004.

48. Park SH, Ko SK and Chung SH: Euonymus alatus prevents the hyperglycemia and hyperlipidemia induced by high-fat diet in ICR mice. J Ethnopharmacol 102: 326-335, 2005.

49. Bookchin RM and Gallop PM: Structure of hemoglobin AIc: Nature of the N-terminal beta chain blocking group. Biochem Biophys Res Commun 32: 86-93, 1968.

50. Larsen ML, Hørder M and Mogensen EF: Effect of long-term monitoring of glycosylated hemoglobin levels in insulindependent diabetes mellitus. N Engl J Med 323: 1021-1025, 1990

51. Sathishsekar D and Subramanian S: Beneficial effects of Momordica charantia seeds in the treatment of STZ-induced diabetes in experimental rats. Biol Pharm Bull 28: 978-983, 2005.

52. Surwit RS, Kuhn CM, Cochrane C, McCubbin JA and Feinglos MN: Diet-induced type II diabetes in C57BL/6J mice. Diabetes 37: 1163-1167, 1988

53. Milburn JL Jr, Hirose H, Lee YH, Nagasawa Y, Ogawa A, Ohneda M, BeltrandelRio H, Newgard CB, Johnson JH and Unger RH: Pancreatic beta-cells in obesity. Evidence for induction of functional, morphologic, and metabolic abnormalities by increased long chain fatty acids. J Biol Chem 270: 1295-1299, 1995.

54. Jia D, Yamamoto M, Otani M and Otsuki M: Bezafibrate on lipids and glucose metabolism in obese diabetic Otsuka Long-Evans Tokushima fatty rats. Metabolism 53: 405-413, 2004.

55. Terauchi Y, Takamoto I, Kubota N, Matsui J, Suzuki R, Komeda K Hara A, Toyoda Y, Miwa I, Aizawa S, et al: Glucokinase and IRS-2 are required for compensatory beta cell hyperplasia in response to high-fat diet-induced insulin resistance. J Clin Invest 117: 246-257, 2007.

56. Noriega-López L, Tovar AR, Gonzalez-Granillo M Hernández-Pando R, Escalante B, Santillán-Doherty $\mathrm{P}$ and Torres N: Pancreatic insulin secretion in rats fed a soy protein high fat diet depends on the interaction between the amino acid pattern and isoflavones. J Biol Chem 282: 20657-20666, 2007.

57. Kamada T, Hata J, Kusunoki H, Ito M, Tanaka S, Kawamura Y, Chayama K and Haruma K: Eradication of Helicobacter pylori increases the incidence of hyperlipidaemia and obesity in peptic ulcer patients. Dig Liver Dis 37: 39-43, 2005.

58. Zdrenghea D, Gligor E, Ossian V and Pop D: The effect of simvastatin associated with ranitidine and alcohol upon serum lipids. Rom J Intern Med 42: 143-148, 2004.

59. Tasso F, Clop J and Sarles H: The interaction of ethanol, dietary lipids and proteins on the rat pancreas. II. Ultrastructural study. Digestion 4: 23-34, 1971.

60. Wilson JS, Korsten MA, Leo MA and Lieber CS: Combined effects of protein deficiency and chronic ethanol consumption on rat pancreas. Dig Dis Sci 33: 1250-1259, 1988.

61. Gartner LP and Hiatt JL: Color Textbook of Histology. 3rd edition. Saunders, Philadelphia, pp417-422, 2007.

62. Ferre T, Riu E, Bosch F and Valera A: Evidence from transgenic mice that glucokinase is rate limiting for glucose utilization in the liver. FASEB J 10: 1213-1218, 1996.
63. Coope GJ, Atkinson AM, Allott C, McKerrecher D, Johnstone C, Pike KG, Holme PC, Vertigan H, Gill D, Coghlan MP, et al: Predictive blood glucose lowering efficacy by Glucokinase activators in high fat fed female Zucker rats. Br J Pharmacol 149: 328-335, 2006.

64. She P, Shiota M, Shelton KD, Chalkley R, Postic C and Magnuson MA: Phosphoenolpyruvate carboxykinase is necessary for the integration of hepatic energy metabolism. Mol Cell Biol 20: 6508-6517, 2000.

65. van Schaftingen E and Gerin I: The glucose-6-phosphatase system. Biochem J 362: 513-532, 2002.

66. Quine SD and Raghu PS: Effects of (-)-epicatechin, a flavonoid on lipid peroxidation and antioxidants in streptozotocin-induced diabetic liver, kidney and heart. Pharmacol Rep 57: 610-615, 2005.

67. Neves RH, Alencar AC, Aguila MB, Mandarim-de-Lacerda CA, Machado-Silva JR and Gomes DC: Hepatic stereology of Schistosomiasis mansoni infected-mice fed a high-fat diet. Mem Inst Oswaldo Cruz 101 (Suppl 1): 253-260, 2006.

68. Garg MC, Singh KP and Bansal DD: Effect of vitamin C supplementation on oxidative stress in experimental diabetes. Indian $\mathrm{J}$ Exp Biol 35: 264-266, 1997.

69. Ceriello A, Quatraro A and Giugliano D: New insights on nonenzymatic glycosylation may lead to therapeutic approaches for the prevention of diabetic complications. Diabet Med 9: 297-299, 1992.

70. Comporti M: Lipid peroxidation and cellular damage in toxic liver injury. Lab Invest 53: 599-623, 1985.

71. Lee YM, Gweon OC, Seo YJ, Im J, Kang MJ, Kim MJ and Kim JI: Antioxidant effect of garlic and aged black garlic in animal model of type 2 diabetes mellitus. Nutr Res Pract 3: 156-161, 2009.

72. Jung UJ, Park YB, Kim SR and Choi MS: Supplementation of persimmon leaf ameliorates hyperglycemia, dyslipidemia and hepatic fat accumulation in type 2 diabetic mice. PLoS One 7: e49030, 2012.

73. Collier A, Wilson R, Bradley H, Thomson JA and Small M: Free radical activity in type 2 diabetes. Diabet Med 7: 27-30, 1990.

74. Giugliano D, Ceriello A and Paolisso G: Oxidative stress and diabetic vascular complications. Diabetes Care 19: 257-267, 1996.

75. Erejuwa OO, Sulaiman SA, Wahab MS, Salam SK, Salleh MS and Gurtu S: Comparison of antioxidant effects of honey, glibenclamide, metformin, and their combinations in the kidneys of streptozotocin-induced diabetic rats. Int J Mol Sci 12: 829-843, 2011.

76. Wu D, Wen W, Qi CL, Zhao RX, Lü JH, Zhong CY and Chen YY: Ameliorative effect of berberine on renal damage in rats with diabetes induced by high-fat diet and streptozotocin. Phytomedicine 19: 712-718, 2012.

77. Odabasoglu F, Cakir A, Suleyman H, Aslan A, Bayir Y, Halici $M$ and Kazaz C: Gastroprotective and antioxidant effects of usnic acid on indomethacin-induced gastric ulcer in rats. J Ethnopharmacol 103: 59-65, 2006.

78. Cheeseman KH and Slater TF: An introduction to free radical biochemistry. Br Med Bull 49: 481-493, 1993.

79. Wu D, Zheng N, Qi K, Cheng H, Sun Z, Gao B, Zhang Y, Pang W, Huangfu C, Ji S, et al: Exogenous hydrogen sulfide mitigates the fatty liver in obese mice through improving lipid metabolism and antioxidant potential. Med Gas Res 5: 1, 2015. 